\title{
Mediterranean irrigation under climate change: more efficient irrigation needed to compensate for increases in irrigation water requirements
}

\author{
M. Fader ${ }^{1,2}$, S. Shi ${ }^{2,4}$, W. von Bloh ${ }^{3}$, A. Bondeau ${ }^{1}$, and W. Cramer ${ }^{1}$ \\ ${ }^{1}$ Institut Méditerranéen de Biodiversité et d'Ecologie marine et continentale, Aix-Marseille Université, CNRS, IRD, Avignon \\ Université, Technopôle Arbois-Méditerranée, Bâtiment Villemin, BP 80, 13545 Aix-en-Provence CEDEX 4, France \\ ${ }^{2}$ Laboratory of Excellence OT-Med. Europôle Méditerranéen de l'Arbois, Bâtiment Gérard Mégie, Avenue Louis Philibert, \\ 13857 Aix-en-Provence CEDEX 3, France \\ ${ }^{3}$ Potsdam Institute for Climate Impact Research, Telegraphenberg, Building A31, 14473 Potsdam, Germany \\ ${ }^{4}$ Research Software Development Group, Research IT Services, University College London, Podium Building, 1st Floor, 1 \\ Eversholt Street, London, NW1 2DN, UK
}

Correspondence to: M. Fader (marianela.fader@imbe.fr)

Received: 15 July 2015 - Published in Hydrol. Earth Syst. Sci. Discuss.: 31 August 2015

Revised: 20 January 2016 - Accepted: 22 January 2016 - Published: 3 March 2016

\begin{abstract}
Irrigation in the Mediterranean is of vital importance for food security, employment and economic development. This study systematically assesses how climate change and increases in atmospheric $\mathrm{CO}_{2}$ concentrations may affect irrigation requirements in the Mediterranean region by 2080-2090. Future demographic change and technological improvements in irrigation systems are taken into account, as is the spread of climate forcing, warming levels and potential realization of the $\mathrm{CO}_{2}$-fertilization effect. Vegetation growth, phenology, agricultural production and irrigation water requirements and withdrawal were simulated with the processbased ecohydrological and agro-ecosystem model LPJmL (Lund-Potsdam-Jena managed Land) after an extensive development that comprised the improved representation of Mediterranean crops. At present the Mediterranean region could save $35 \%$ of water by implementing more efficient irrigation and conveyance systems. Some countries such as Syria, Egypt and Turkey have a higher savings potential than others. Currently some crops, especially sugar cane and agricultural trees, consume on average more irrigation water per hectare than annual crops. Different crops show different magnitudes of changes in net irrigation requirements due to climate change, the increases being most pronounced in agricultural trees. The Mediterranean area as a whole may face an increase in gross irrigation requirements between 4 and
\end{abstract}

$18 \%$ from climate change alone if irrigation systems and conveyance are not improved ( 4 and $18 \%$ with $2{ }^{\circ} \mathrm{C}$ global warming combined with the full $\mathrm{CO}_{2}$-fertilization effect and $5{ }^{\circ} \mathrm{C}$ global warming combined with no $\mathrm{CO}_{2}$-fertilization effect, respectively). Population growth increases these numbers to 22 and $74 \%$, respectively, affecting mainly the southern and eastern Mediterranean. However, improved irrigation technologies and conveyance systems have a large water saving potential, especially in the eastern Mediterranean, and may be able to compensate to some degree for the increases due to climate change and population growth. Both subregions would need around $35 \%$ more water than today if they implement some degree of modernization of irrigation and conveyance systems and benefit from the $\mathrm{CO}_{2}$-fertilization effect. Nevertheless, water scarcity may pose further challenges to the agricultural sector: Algeria, Libya, Israel, Jordan, Lebanon, Syria, Serbia, Morocco, Tunisia and Spain have a high risk of not being able to sustainably meet future irrigation water requirements in some scenarios. The results presented in this study point to the necessity of performing further research on climate-friendly agro-ecosystems in order to assess, on the one hand, their degree of resilience to climate shocks and, on the other hand, their adaptation potential when confronted with higher temperatures and changes in water availability. 


\section{Introduction}

Water is a scarce resource in the Mediterranean region, not only in absolute terms but also through the concentration of precipitation in the winter months and the high interannual variability with the presence of frequent droughts (Lionello et al., 2006). Climate change is expected to exacerbate this situation by increasing potential evapotranspiration, decreasing rainfall and increasing the frequency and intensity of droughts (Niang et al., 2014; IPCC, 2014). For example Vautard et al. (2014) calculated precipitation decreases reaching $20 \%$ for $2{ }^{\circ} \mathrm{C}$ global warming and state that southern Europe is likely to experience higher warming than the global average, especially in summer. Additionally, minimum river flows in southern Europe may be lowered by up to $40 \%$ by the middle of the century and streamflow drought conditions may continue to be intensified by human water consumption, especially due to irrigation (Forzieri et al., 2014).

Climate change is not the only factor affecting water supply and demand; population and economic growth in the countries of the southern Mediterranean and urbanization in the entire Mediterranean region will very likely further increase water extractions. The urban population in northern Africa and southern Europe is expected to increase from 51 to $63 \%$ and from 70 to $80 \%$, respectively (United Nations, 2014), leading to more water consumption, higher water demand for energy production and changes in hygiene behaviour. Additional pressure on water resources may arise in the southern coastal areas through increased water use for new industries and in the northern coastal areas due to the expansion of biofuel plantations (the EU has the objective of supplying $10 \%$ of transport fuel through biofuels by 2020; EU, 2007). Moreover, the expansion of tourism is expected to increase water demand, especially in the dry period (Lanquar, 2013).

The combination of these factors will very likely intensify the debate on the allocation of water resources between the different economic sectors and intensify the requirements of increasing the water use efficiency in all of them. The agricultural sector of the Mediterranean may be strongly affected by this debate since agriculture is the sector that contributes the most to water withdrawal. On average, around $50 \%$ of total water withdrawal in the Mediterranean is for agriculture, with strong subregional patterns from around $1.3 \%$ in Croatia and $12 \%$ in France up to almost $90 \%$ in Syria, Egypt, Cyprus and Greece (FAO, 2015). These proportions are expected to further increase in future, especially in the developing subregions (Faurès et al., 2000). Further complexity is added to these issues by the fact that there are environmental concerns linked to irrigated agriculture, including groundwater over-exploitation and negative consequences of unsustainable management, such as salinization (Souissi et al., 2013). However, deallocating water resources from the agricultural sector would affect food security, the economy and the environment. For example, ir- rigated agriculture contributes $28 \%$ of GDP in Syria and produces USD $\sim 33.7$ billion in Spain (Rodríguez-Díaz and Topcu, 2010; Manero, 2008), employs 400000 people in southern France (AIRMF, 2009) and provides ecosystem services, such as landscape preservation and biodiversity conservation (Nieto-Romero et al., 2014).

All this makes it certain that irrigated agriculture will be at the core of the future discussion on the allocation of water resources. Coping with this situation without damaging the agricultural sector and while providing the water needed by the other sectors will require informed discussions and decisions based on quantitative assessments. Those quantifications, necessarily, will have to include estimations about the present and future water requirements for irrigated agriculture as well as the water saving potential in this sector. However, to date, only few comprehensive studies have been made on estimations of future irrigation requirements, as reviewed in the following paragraph.

Doell and Siebert (2002) were probably the first to quantify irrigation water requirements at the global level. They distinguished two crop classes (rice and non-rice), analysed with two global climate models (GCMs) and pointed out the effect of higher climate variability on future irrigation requirement. In a later study, Siebert et al. (2010) computed irrigation consumptive water use by means of the Global Crop Water Model (GCWM) for the present time. Using the FAO's agro-ecological zones model, Fischer et al. (2007) presented estimations of future irrigation water requirements under mitigated and unmitigated climate change for different regions, including western Europe, the Middle East and northern Africa. They came to the conclusion that the Middle East and northern Africa may be affected by a high water scarcity in 2080, indicating potential difficulties for meeting future irrigation water requirements. They also indicated that mitigation of climate change would reduce increases in irrigation requirements, the effect in Europe being larger than in northern Africa. Konzmann et al. (2013) presented simulated future irrigation requirements globally for around 10 crop functional types under 19 GCMs with a previous version of the LPJmL (Lund-Potsdam-Jena managed Land) model (without the representation of irrigated agricultural trees) and came to the conclusion that the Mediterranean region may need more water under climate change. Souissi et al. (2013) compiled data from various sources, showing estimates of irrigation water use of $181 \mathrm{~km}^{3}$ per year in 2005 for the Mediterranean region. For 2025, they show a range of 157 to $212 \mathrm{~km}^{3}$, depending on the scenario (business as usual or sustainable development in relation to water resources policies), pointing to possible savings in irrigation water but also to potential increases in irrigation water requirements. Elliot et al. (2014) pointed to the risk of increasing irrigation water requirements under climate change in some regions, including the Mediterranean. These conclusions are complemented by a number of local-scale studies, focused on a reduced number of crops, for example Teyssier (2006) 
for the Midi-Pyrénées region in France and Rodríguez-Díaz et al. (2007) for the Guadalquivir river basin in Spain. The literature review shows some common elements, indicating that the Mediterranean region may suffer in the future from a combination of increased water scarcity and higher water demand.

The present study aims to advance substantially the present research status by taking into account, in a comprehensive framework, several previously unconsidered variables: climate change impacts on irrigation water requirements in the Mediterranean region are simulated with a newly developed version of the LPJmL model that considers $88 \%$ of irrigated areas and represents the special structure of Mediterranean agriculture, which is dominated by perennial crops (Fader et al., 2015). The simulations are performed for four warming levels and 19 GCMs. LPJmL (Sitch et al., 2003; Bondeau et al., 2007; Gerten el al., 2004; Schapfhof et al., 2013) is a mechanistic hydrology and agro-ecosystem model that has important features for the quantification of irrigation requirements, such as a dynamic coupling of water, agricultural production and plant physiology, and for the consideration of changes in phenology through to dynamic growing periods, sowing dates and flowering times. Additionally, we consider in this study the link between demographic change and water demand as well as the possibility of improving irrigation and conveyance systems in future by adopting water saving technologies and infrastructure.

One of the largest uncertainties in climate change impact research related to vegetation is the effect of higher $\mathrm{CO}_{2}$ concentrations in the atmosphere on plant growth, phenology, water requirements and production. In general higher $\mathrm{CO}_{2}$ in the atmosphere has the potential to increase photosynthesis and water productivity of plants, especially the ones with C3 photosynthetic pathways (Hatfield et al., 2011; Ackerman and Stanton, 2013). This is why this effect has been called the " $\mathrm{CO}_{2}$-fertilization effect". Nevertheless, the environmental and genotype dependencies and consequences of co-limitations (especially nutrients and water) as well as the order of magnitude of the $\mathrm{CO}_{2}$-fertilization effect and changes in nutritional values are still uncertain (Porter et al., 2014; DaMatta et al., 2010). For example, DaMatta et al. (2010) reviewed literature and came to the conclusion that the beneficial effect of $\mathrm{CO}_{2}$ could be offset by higher temperatures and altered precipitation patterns. FACE (free-air $\mathrm{CO}_{2}$ enrichment) experiments, enclosure study measurements and modelling efforts have tried and are trying to shed light on this issue but have not given consistent results so far (Long et al., 2006; Tubiello et al., 2007; Ainsworth et al., 2008). Modelling experiments usually deal with this uncertainty by making two sets of simulations: one using dynamic $\mathrm{CO}_{2}$ concentrations in the atmosphere as inputs and one with constant $\mathrm{CO}_{2}$ concentrations. The responses of vegetation will very likely fall in the range of these two extremes, and in order to assess this in-between space in more detail, we addition- ally take one more scenario into account, which represents a "reduced" $\mathrm{CO}_{2}$-fertilization effect.

Hence, this study aims to answer the following research questions:

1. How much irrigation water do we need today in the Mediterranean region? What are the most waterintensive crops?

2. Which countries have the potential for saving water through changes in the irrigation and conveyance systems?

3. How do different levels of climate change impact future irrigation requirements? Are there subregional patterns (east, south, north)?

4. Are different crops affected differently by climate change?

5. What is the potential role of demographic change and water scarcity?

Section 2 gives an overview of the methodology of the study, including model functioning, $\mathrm{CO}_{2}$-fertilization scenarios and scenarios of improvements in irrigation technologies. Section 3 presents the results for the present irrigation requirements and changes under climate, demographic and technological change. Section 4 shows possible implications and discusses prospects for further research.

\section{Methods}

Vegetation growth, phenology, agricultural production and irrigation water requirements and withdrawal were simulated with the process-based agro-ecosystem and hydrology model LPJmL (Sitch et al., 2003; Bondeau et al., 2007; Rost et al., 2008; Gerten el al., 2004; Schapfhof et al., 2013). LPJmL was recently developed for the inclusion of Mediterranean crops by Fader et al. (2015); the result is a model that considers $88 \%$ of irrigated areas divided into 12 annual crops (temperate cereals, rice, tropical cereals, maize, temperate roots, tropical roots, pulses, rapeseed, soybeans, sunflower, sugar cane, potatoes), 7 perennial crops or crop classes (nut trees, date palms, citrus trees, non-citrus orchards, olive trees, grapevine, cotton) and 4 groups parameterized as herbaceous crops (fodder grass, vegetables, managed grasslands, "other crops").

Annual crops grow and are harvested according to the heat unit theory and agricultural trees are implemented as evergreen or summer green trees, where the fruits are represented by a plant-specific portion of net primary productivity (NPP). Vegetables and fodder grasses are parameterized as C3 grass and managed grasslands as a mixture of C3 and C4 grasses (see Bondeau et al. (2007) and Fader et al. (2015) for more details). Agricultural management is calibrated to best match 
FAO yields (FAOSTAT, 2014), both for annual and perennial crops. This routine represents differences in management intensity (see Fader et al. $(2010,2015)$ for more details).

Model inputs consist of climate variables and global $\mathrm{CO}_{2}$ concentrations (see below), soil texture as described in Schaphoff et al. (2013), and a data set of land use patterns compiled from different sources as explained in Fader et al. (2015) (see Fig. S1 in the Supplement for crop-specific areas in the Mediterranean region).

Climate data for the present and past was taken from the Climate Research Unit data set (University of East Anglia, CRU 3.10) for temperature and cloudiness and from the Global Precipitation Climatology Centre's (GPCC; version 5; Rudolf et al., 2010) for precipitation and cloudiness. For the climate change simulations, the PanClim data set from Heinke et al. (2013) was used. They performed pattern downscaling of GCM data using global mean temperature and greenhouse gas trajectories from a reduced complexity climate model (MAGICC6; Meinshausen et al., 2011) to derive climate scenarios covering warming levels from 2 to $5^{\circ}$ above pre-industrial levels around the year 2100 .

We take the effect of higher $\mathrm{CO}_{2}$ concentrations in the atmosphere into account by analysing three scenarios.

- Dynamic $\mathrm{CO}_{2}$ (DYN): LPJmL runs with the corresponding global $\mathrm{CO}_{2}$ concentrations (from the MAGICC6 model; see Heinke et al., 2013) in accordance with each warming level. DYN assumes a full $\mathrm{CO}_{2}$ fertilization effect and no limitation of this effect through lack of other resources (most notably soil nutrients).

- Reduced $\mathrm{CO}_{2}$ (RED): this scenario assumes that the $\mathrm{CO}_{2}$-fertilization effect will occur but for higher warming levels and less strongly than in DYN. Technically, we implemented this using the $\mathrm{CO}_{2}$ concentration values of one lower warming level. For example, the $\mathrm{CO}_{2}$ concentrations of $4^{\circ}$ warming DYN are the same as the $5^{\circ}$ warming RED, but the climate forcing is different.

- Constant $\mathrm{CO}_{2}$ (CONST): this scenario assumes that plants will not benefit from $\mathrm{CO}_{2}$ fertilization due to management deficiencies, lack of resources, climatic stress and higher frequency of extreme events. Technically, we implement this by keeping $\mathrm{CO}_{2}$ concentrations constant at the level of 2009 (387.85 ppm), while varying climate forcing according to the different warming levels.

The $\mathrm{CO}_{2}$ concentration trajectories for all of these scenarios are plotted in Fig. S2. In LPJmL the potential, non-waterlimited canopy conductance of carbon and water depends on crop-specific net photosynthesis and the stomata-controlled ratio between ambient and intercellular $\mathrm{CO}_{2}$ partial pressure. This ratio is dynamically simulated by LPJmL but has maximum values slightly different for $\mathrm{C} 3$ and $\mathrm{C} 4$ plants ( 0.8 for
C3 plants and 0.4 for C4 plants) under non-water-stressed conditions. Atmospheric demand (i.e. "unstressed transpiration") follows a hyperbolic function of canopy conductance and is included, in turn, into the calculation of net irrigation requirements (see below). Thus, with higher $\mathrm{CO}_{2}$ concentrations in the atmosphere plants transpire less per unit of carbon fixed, i.e. they are more water efficient, and this may reduce irrigation water requirements. However, since $\mathrm{CO}_{2}$ is a limiting factor for most agricultural plants (especially $\mathrm{C} 3$ plants), higher $\mathrm{CO}_{2}$ concentrations in the atmosphere stimulate photosynthesis and increase net primary productivity, biomass formation, and thus total transpiration and irrigation requirements. Additionally, these changes in transpiration are coupled with changes in soil evaporation (which decreases with increases in shadow effects from increased biomass) and plants' water interception (which increases due to a higher leaf area from the stimulation of productivity) (see more details in Sitch et al., 2003, and Gerten et al., 2004).

\subsection{Irrigation water requirements, water withdrawal and transformation of irrigation systems}

Irrigation in LPJmL is triggered in irrigated areas when soil water content is lower than $90 \%$ of field capacity in the upper $50 \mathrm{~cm}$ of the soil (the so-called "irrigated layer"). The soil water content of the irrigation layer depends on climatic variables (notably temperature and rainfall), vertical and horizontal water movements, soil evaporation, and also plants' water extraction by roots. Plants' net irrigation water requirements (NIR) are modelled as the amount of water that plants need, taking into account the relative soil moisture and the water-holding capacity of the irrigated layer:

$\mathrm{NIR}\left[\mathrm{mmday}^{-1}\right]=\min \left(\frac{1}{f_{\mathrm{Ril}}}\left(\frac{D}{S y}-w_{\mathrm{r}}\right), 1-w_{\mathrm{il}}\right) \mathrm{WHC}$,

where $D\left(\mathrm{~mm} \mathrm{day}^{-1}\right)$ is the atmospheric demand, which depends on potential evapotranspiration and potential canopy conductance. When the canopy is dry and potential evapotranspiration tends to infinity, demand approximates the multiplication of the daily equilibrium evapotranspiration rate (which depends mainly on net radiation and temperature) and the maximum Priestley-Taylor coefficient (1.391) with a hyperbolic function. $S y\left(\mathrm{~mm} \mathrm{day}^{-1}\right)$ is the soil water supply, which equals a crop's specific maximum transpirational rate at field capacity or declines linearly with soil moisture. $f_{\text {Ril }}$ is the proportion of roots in the irrigated layer. $w_{\text {il }}$ is the water content in the irrigated layer. $w_{\mathrm{r}}$ is the water content weighted with the root density for the soil column. WHC (water-holding capacity; $\mathrm{mm}$ ) is a soil-texture-dependent parameter that represents the water content at field capacity (see Schaphoff et al., 2013).

Water withdrawal or extraction, also called gross irrigation water requirements (GIR), is obtained by dividing NIR by the project efficiencies (EP): 
Table 1. Left four columns: efficiencies linked to irrigation and conveyance systems. EA: field application efficiency. EC: conveyance efficiency. Right two columns: explanation of the implementation of the improved irrigation scenario (IMP). For example, a country with surface irrigation and open channels, will, in the IMP scenario, move to a combination of surface and sprinkler irrigation and to mixedconveyance system (channels and pipelines).

\begin{tabular}{llllll}
\hline $\begin{array}{l}\text { Current } \\
\text { predominant } \\
\text { irrigation } \\
\text { system }\end{array}$ & $\begin{array}{l}\text { Current } \\
\text { conveyance } \\
\text { system }\end{array}$ & EA & EC & $\begin{array}{l}\text { Improved } \\
\text { irrigation } \\
\text { system }\end{array}$ & $\begin{array}{l}\text { Improved } \\
\text { conveyance } \\
\text { system }\end{array}$ \\
\hline Surface & $\begin{array}{l}\text { Open } \\
\text { channels }\end{array}$ & 0.6 & 0.7 & $\begin{array}{l}\text { Mixed } \\
\text { (surface } \\
\text { sprinkler) }\end{array}$ & $\begin{array}{l}\text { Open channels and } \\
\text { pipelines }\end{array}$ \\
\hline $\begin{array}{l}\text { Mixed } \\
\text { (surface and } \\
\text { sprinkler) }\end{array}$ & $\begin{array}{l}\text { Open } \\
\text { channels and } \\
\text { pipelines }\end{array}$ & 0.675 & 0.825 & Sprinkler & Pipelines \\
\hline Sprinkler & Pipelines & 0.75 & 0.95 & Drip & Pipelines \\
\hline Drip & Pipelines & 0.9 & 0.95 & Drip & Pipelines \\
\hline
\end{tabular}

$\operatorname{GIR}\left[\mathrm{mmday}^{-1}\right]=\frac{\mathrm{NIR}}{\mathrm{EP}}$.

EP is a dimensionless country-specific parameter calculated by Rohwer et al. (2006), taking into account reported data on conveyance efficiency (EC), field application efficiency (EA) and a management factor of the irrigation system $(\mathrm{MF})$ :

$\mathrm{EP}[0$ to $<1]=\mathrm{EC} \cdot \mathrm{EA} \cdot \mathrm{MF}$.

EA represents the water use efficiency in the fields and increases from surface irrigation systems to mixed (sprinkler and surface systems) and pure sprinkler systems to drip irrigation systems. EC represents the water use efficiency in the distribution-conveyance systems usually belonging to farmer associations, and it is assumed to be linked to irrigation systems. Thus, EC is smaller for surface irrigation systems (with water assumed to be supplied by open channels) than for sprinkler and drip irrigation systems, which are assumed to function with water supplied by pressurized pipelines. MF varies between 0.9 and 1 and is higher in pressurized and small-scale systems under the assumption that large-scale systems are more difficult to manage and, thus, prone to have slightly lower efficiency in water use, especially when surface irrigation comes into play (see values in Table 1 and more details in Rohwer et al., 2006).

In order to test the potential for water savings through more efficient irrigation and conveyance systems, we assume two more scenarios with improvements in irrigation systems and water conveyance infrastructures in addition to the status quo regarding irrigation efficiencies as explained above.

- Improvement scenario (IMP): adoption of more waterefficient irrigation and conveyance systems. In this scenario it is assumed that one level of improvement in irrigation systems is achieved in every country of the region (as shown in Table 1). Technically, we implemented this in a set of climate change runs with changed EP parameters, assuming a higher efficiency in irrigation and conveyance systems (see Eq. (3) and Table 1).

- Most efficient scenario (DRIP): in this scenario, it is assumed that all countries of the region implement drip irrigation systems combined with water conveyance through pipelines.

- Standard scenario (STS): this scenario represents the business-as-usual possibility, where irrigation and conveyance systems remain as they are at the present time.

\subsection{Simulation protocol and descriptive statistics}

Three simulations (STS, IMP, DRIP) were performed for the present time and analysed as means over the years 2000 to 2009.

In total, 684 simulations were performed for the future: $19 \mathrm{GCMs}, 4$ warming levels (from 2 to $5^{\circ}$ in $1^{\circ} \mathrm{C}$ steps), 3 $\mathrm{CO}_{2}$-fertilization scenarios (DYN, CONST, RED), 3 irrigation scenarios (IMP, DRIP, STS). Results are evaluated for the period 2080 to 2090 as medians or means as explained by the following equations.

Region and subregion medians and simple means over GCMs were computed as last steps after averaging over years and aggregation over grid cells and crops as follows:

$$
\begin{aligned}
& \mathrm{NIR}_{80-90, \mathrm{GCM} x}\left[\mathrm{~km}^{3}\right] \\
& =\frac{\sum_{P=1}^{n} \sum_{\mathrm{cr}=1}^{n}\left(\left(\sum_{Y=1}^{n} \mathrm{NIR}_{Y, P, \mathrm{cr}} \cdot 10 \cdot \operatorname{area}_{Y, P, \mathrm{cr}}\right) / n Y\right)}{10^{9}},
\end{aligned}
$$

where $\mathrm{NIR}_{Y, P, \mathrm{cr}}\left(\mathrm{mm} \mathrm{day}^{-1}\right)$ represents the net irrigation requirement of a crop (cr), for year $(Y)$, in a grid cell $(P)$, ac- 
cording to one GCM (GCM $x)$. Area (ha) is the irrigated area covered in $P$ by the cr. $n Y$ is the number of years for the period evaluated (11 for 2080 to 2090). A factor of 10 is used to convert values from millimetres to cubic metres per hectare, and $10^{9}$ is used to convert cubic metres to cubic kilometres.

Spatial explicit changes in variables are computed for each scenario and GCM separately as

$\mathrm{NIR} \_C h a n g e_{P}[\%]=\frac{\mathrm{NIR}_{80-90, G C M}, P}{\mathrm{NIR}_{00-09, P}} \cdot 100-100$.

Thus, negative (positive) values represent decreases (increases).

\subsection{Influence of demographic change}

For all combinations of irrigation systems, $\mathrm{CO}_{2}$-fertilization effect and warming scenarios, the influence of demographic change was taken into account as shown in Eq. (6).

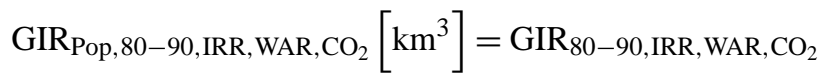

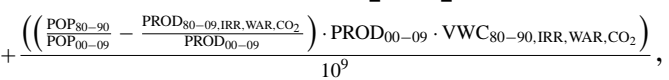

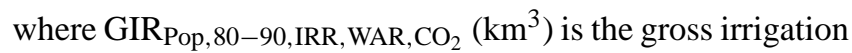
requirement, as an average over the period of 2080-2090 and adjusted for population growth (Pop) for the irrigation scenario IRR (STS, IMP, DRIP), the warming level WAR and the $\mathrm{CO}_{2}$-fertilization scenario $\mathrm{CO}_{2}$ (DYN, CONST, RED).

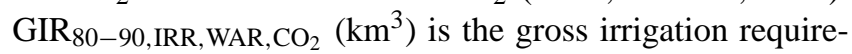
ment as computed in every combination of IRR, WAR and $\mathrm{CO}_{2}$ without the influence of demographic change. POP (hab) is the population numbers from the medium fertility scenario in United Nations (2013). PROD (t) is the irrigated production of agricultural goods. VWC $\left(\mathrm{m}^{3} \mathrm{t}^{-1}\right)$ is the virtual water content of irrigated agricultural products calculated as gross irrigation requirements divided by production. GIR, PROD and VWC are medians over the 19 GCM runs; $10^{9}$ is used to convert values from cubic metres to cubic kilometres.

This computation takes into account the production gains and losses through different levels of climate change and $\mathrm{CO}_{2}$ fertilization as well as the changes in the productivity of irrigation water (i.e. changes in VWC). The output of this approach assumes that population change will linearly decrease or increase food demand and sheds light on future irrigation requirements in the case of (a) no future increases in import dependency by increases in virtual water imports, (b) unchanged diets, and (c) unchanged proportions of irrigated to rainfed areas in the case of agricultural expansion and no changes in agricultural management besides the ones linked to modernization of irrigation systems.

\subsection{Influence of water scarcity}

A quantification of water scarcity for future irrigation requirements was carried out by comparing the simulated irrigation water requirements under climate change (with and without demographic change) with four water availability scenarios. These renewable water availability scenarios (RWA) were calculated on the basis of AQUASTAT data for the current time at national level (FAO, 2015). They differ in the external inflows considered as well as in whether they consider environmental flow requirements or not.

For the politically assured, sustainable scenario (POL_SUS), we only consider the external inflow secured through treaties at present and exclude water needed by aquatic ecosystems. Thus, the calculation is

$$
\begin{aligned}
\text { RWA }_{P O L} \_ \text {SUS } & {\left[\mathrm{km}^{3}\right]=\mathrm{RWR}_{\mathrm{I}, \mathrm{S}+\mathrm{G}}+\text { Inflow }_{\mathrm{E}, \mathrm{S}, \mathrm{T}} } \\
& - \text { Outflow }_{\mathrm{E}, \mathrm{S}, \mathrm{T}}+\text { Inflow }_{\mathrm{E}, \mathrm{G}}-\text { Outflow }_{\mathrm{E}, \mathrm{G}} \\
& + \text { BorderRWR }_{\text {Lakes }+ \text { Rivers }}-\mathrm{WU}_{\text {municipal }} \\
& -\mathrm{WU}_{\text {industry }}-\mathrm{EF}_{\mathrm{S}}-V_{\mathrm{S}+\mathrm{G}},
\end{aligned}
$$

where RWA is the renewable water availability in the politically assured, sustainable scenario. $\mathrm{RWR}_{\mathrm{I}, \mathrm{S}+\mathrm{G}}$ represents the renewable water resources as a sum of the internally (I) produced surface (S) and groundwater (G). Double counting is avoided by considering the overlap variable of AQUASTAT. Outflow $\mathrm{W}_{\mathrm{S}, \mathrm{T}}$ and Inflow $\mathrm{E}, \mathrm{S}, \mathrm{T}$ are the surface water outflow and inflow from and to other countries, respectively, secured through treaties $(T)$. Inflow ${ }_{E, G}$ and Outflow $\mathrm{E}_{\mathrm{G}}$ are the groundwater entering and leaving the

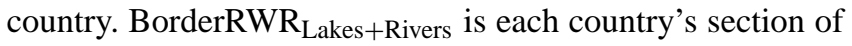
border lakes and rivers. $\mathrm{WU}_{X}$ is the water withdrawal for industry and municipal use. $\mathrm{EF}_{S}$ is equal to $30 \%$ of internally produced $\mathrm{RWR}_{\mathrm{I}, \mathrm{S}}$ and represents the water needed for conservation of aquatic ecosystems, an assumption widely used in the hydrological community. $V$ is equal to $30 \%$ of internally produced $\mathrm{RWR}_{\mathrm{I}, \mathrm{S}+\mathrm{G}}$ and represents the amount of water that is unavailable due to technical difficulties, lack of infrastructure, temporal variability, and mismatching of temporal availability and spatial needs.

In the second given, sustainable scenario (GIV_SUS) we additionally take external inflows not submitted to treaties into account (Inflow $\left.\mathrm{E}_{\mathrm{S}, \mathrm{noT}}\right)$ :

$$
\begin{aligned}
\text { RWA }_{\text {GIV_SUS }} & {\left[\mathrm{km}^{3}\right]=\mathrm{RWR}_{\mathrm{I}, \mathrm{S}+\mathrm{G}} } \\
& + \text { Inflow }_{\mathrm{E}, \mathrm{S}, \mathrm{T}}+\text { Inflow }_{\mathrm{E}, \mathrm{S}, \mathrm{noT}}-\text { Outflow }_{\mathrm{E}, \mathrm{S}, \mathrm{T}} \\
& + \text { Inflow }_{\mathrm{E}, \mathrm{G}}-\text { Outflow }_{\mathrm{E}, \mathrm{G}} \\
& + \text { BorderRWR }_{\mathrm{Lakes}+\text { Rivers }}-\mathrm{WU}_{\text {municipal }} \\
& -\mathrm{WU}_{\text {industry }}-\mathrm{EF}_{\mathrm{S}}-V_{\mathrm{S}+\mathrm{G}}
\end{aligned}
$$

Not considering environmental flow requirements in Eqs. (7) and (8) yields the politically assured, unsustainable scenario (POL_UNSUS) and the given, unsustainable scenario (GIV_UNSUS), respectively.

AQUASTAT data are for the present time, and thus they do not consider changes in water availability due to climate change and increases in water demands through other sectors. 

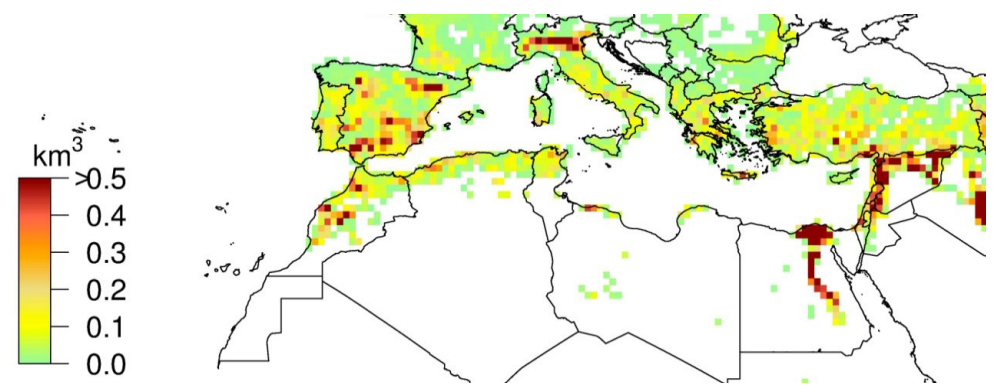

Figure 1. Annual absolute gross irrigation water requirements (GIR), as average for the period 2000-2009, at a 30 arcmin resolution.

Maximal and median GIR under climate change, with and without the influence of population change and transformation of irrigation systems, are compared to these scenarios for the period of 2080-2090.

\section{Results}

\subsection{Mediterranean region could save $35 \%$ of water at present}

Figure 1 shows patterns of GIR in absolute terms for the present time. Irrigation water withdrawals are especially high in the Nile Delta, the Po Valley, in the eastern Mediterranean and in some Spanish regions. In total, the agricultural sector in the Mediterranean was simulated to withdraw $\approx 223 \mathrm{~km}^{3}$ of water per year for irrigation (average 2000-2009). Only around $128 \mathrm{~km}^{3}$ of this amount represent the quantity of water directly required by plants (NIR). Hence, around $95 \mathrm{~km}^{3}$ of water infiltrates the ground, evaporates, or leaks on the way to the plants before being productively used for photosynthesis.

Figure 2a shows irrigation water requirements (coloured in blue) and green water consumption on irrigated areas (coloured in green) in the Mediterranean region, ordered from the highest to the lowest NIR. Green water is the precipitation water stored in the soil and directly available for plants. Adding both values yields the crop water needs. Sugar cane, mostly cultivated in Morocco and Egypt, is the most water-intensive crop of the region (Fig. 2a). Also, date palms, citrus and olives have irrigation water requirements above $7000 \mathrm{~m}^{3} \mathrm{ha}^{-1}$. Nonetheless, when considering absolute values of NIR (not shown), as opposed to values per hectare, temperate cereals, maize, olives and cotton, with NIR above $10 \mathrm{~km}^{3}$ each, are the strongest water consumers (see cropspecific irrigated areas in the Supplement, Fig. S1). Nevertheless, caution is imperative when interpreting both indicators (absolute and per hectare), since they represent averages and sums that are not independent of the location of cultivation areas and, thus, are influenced by the patterns of potential evapotranspiration.
Our simulations indicate that the Mediterranean region could save $35 \%$ of water by strongly improving the irrigation systems and the conveyance infrastructure: GIR for the DRIP scenario amount to $\sim 143 \mathrm{~km}^{3}$. A less dramatic improvement (IMP) yields $10 \%$ water savings $\left(\mathrm{GIR}=\sim 200 \mathrm{~km}^{3}\right)$. Especially Egypt, Turkey, Spain and Syria could save large amounts of water through a switch to more efficient irrigation systems and infrastructure (Fig. 2b). On the contrary, for example Libya and Tunisia have not only lower irrigation water requirements but also much reduced possibilities for saving water through the optimization of irrigation systems and conveyance (Fig. 2b).

Fader et al. (2015) showed a good agreement with other estimates for NIR at national and subnational levels and for GIR at national level. Souissi et al. (2013) compiled data from various sources, showing estimates of irrigation water use of $181 \mathrm{~km}^{3}$ per year in 2005 for the Mediterranean region. It is unclear whether they refer to net or gross irrigation requirements, but this value is within the range defined by our NIR and GIR values (128 and $223 \mathrm{~km}^{3}$, respectively). Blinda (2012) estimated the water demand for irrigation use at $181.3 \mathrm{~km}^{3}$ in 2005 (Mediterranean area excluding Portugal, Serbia and Jordan) and the water lost during conveyance and distribution at $100 \mathrm{~km}^{3}$. It is not clear how they computed or collected the data. These numbers are close to ours (223 and $95 \mathrm{~km}^{3}$, respectively).

The ratio of NIR to GIR in our study is $57 \%$ and represents the current irrigation efficiency. This is in very good agreement with Fischer et al. (2007), who calculated an irrigation efficiency of $58 \%$ (average of western Europe, defined by these authors as including southern Europe and Turkey, and of the Middle East and northern Africa).

There is a general lack of data on crop water needs; hence, only rather old data from FAO (1986) could be compared with our estimates (see error bars in Fig. 2a). FAO values are very generic, i.e. without differentiation for period of time, region, climate and soil. The comparison yields a fair agreement with our values for some crops but shows that spatially inexplicit data may overestimate the water needs for sugar cane, fodder grass, sunflower, tropical cereals and potatoes in the Mediterranean region. 
(a)

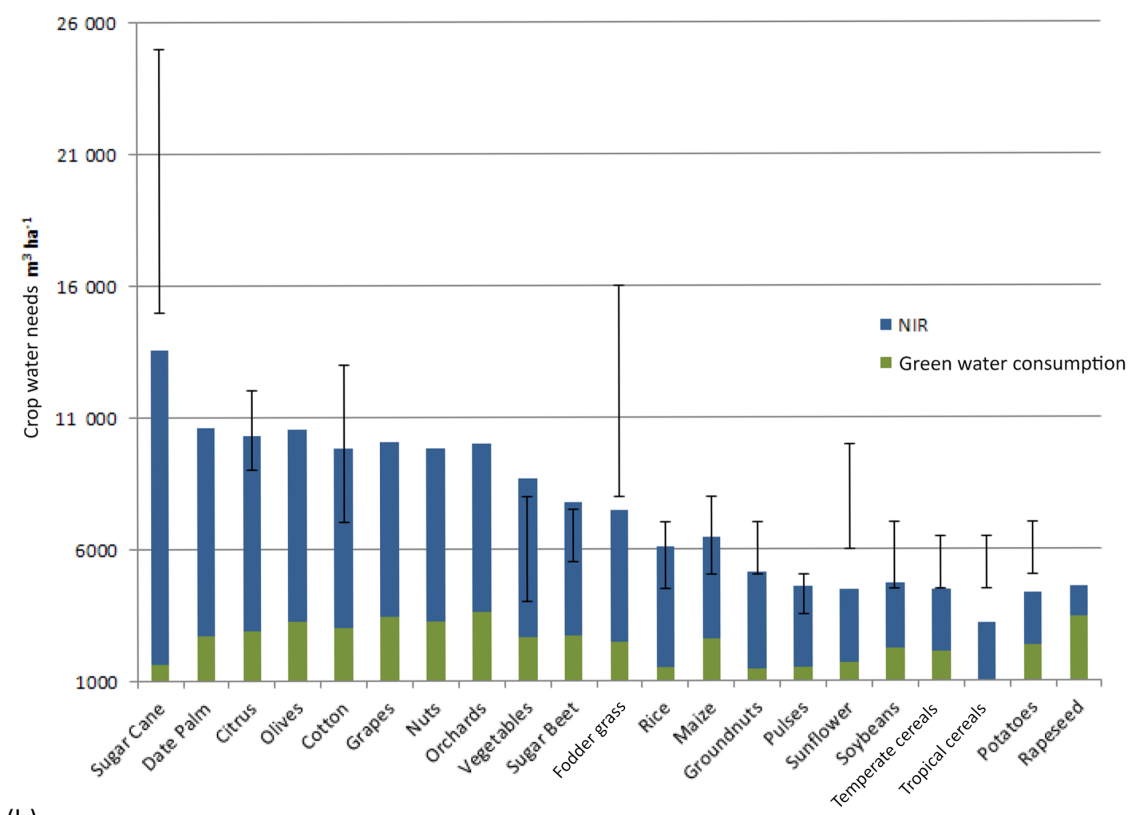

(b)

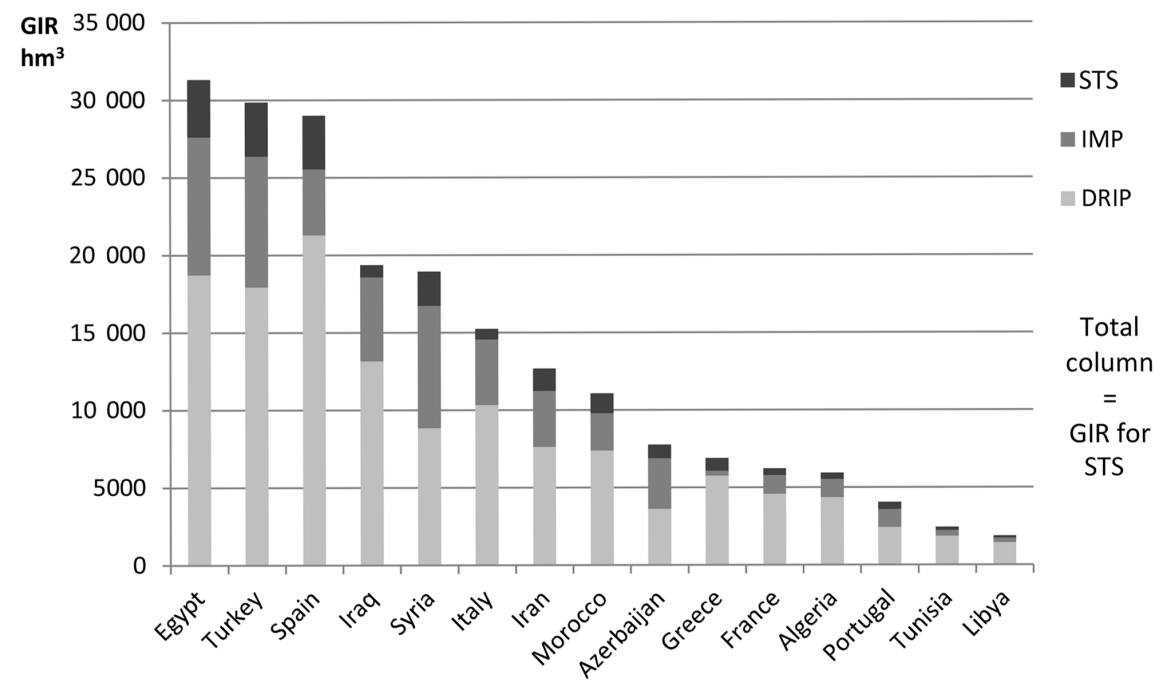

Figure 2. Panel (a): net irrigation requirements and green water consumption aggregated for different crops in the Mediterranean region, as average of 2000-2009. Total bar height represents the crop water needs. Error bars show the maximum and minimum values for crop water needs published by FAO (1986). Note that the $y$ axis starts at $1000 \mathrm{~m}^{3} \mathrm{ha}^{-1}$. Panel (b): national gross irrigation water requirements (GIR) for current irrigation systems (STS), improved irrigation systems (IMP) and optimized irrigation systems (DRIP) as the average of the period 2000-2009.

\subsection{Climate change will increase irrigation water requirements in the future}

Without improvements in irrigation technologies and irrigation water conveyance (STS), considering no effects of higher $\mathrm{CO}_{2}$ concentrations (CONST) and looking at the $5{ }^{\circ} \mathrm{C}$ warming trajectory, GIR increase by around $18 \%$ up to $\sim 264 \mathrm{~km}^{3}$ in 2080-2090 (median of 19 GCMs; Fig. 3). The median precipitation in this trajectory by the end of the century is around $5300 \mathrm{~km}^{3}$ for the Mediterranean re- gion as a whole, as opposed to $6000 \mathrm{~km}^{3}$ at present, implying a $10 \%$ decrease. However, the spread of GCM values is considerable, with values between a 4 and $23 \%$ decrease in precipitation (see Figs. S3-S5 for time series). The full $\mathrm{CO}_{2}$-fertilization effect (DYN) and the lowest warming level $\left(2{ }^{\circ} \mathrm{C}\right.$ ) yield a much lower GIR increase of about $4 \%$ (Fig. 3 ). In this trajectory changes in precipitation are less uncertain with a median precipitation decrease of $4 \%$ (GCM range between 2 and $10 \%$ decrease; see Figs. S3-S5). The influence of outlier GCMs was explored by calculating the GIR aver- 


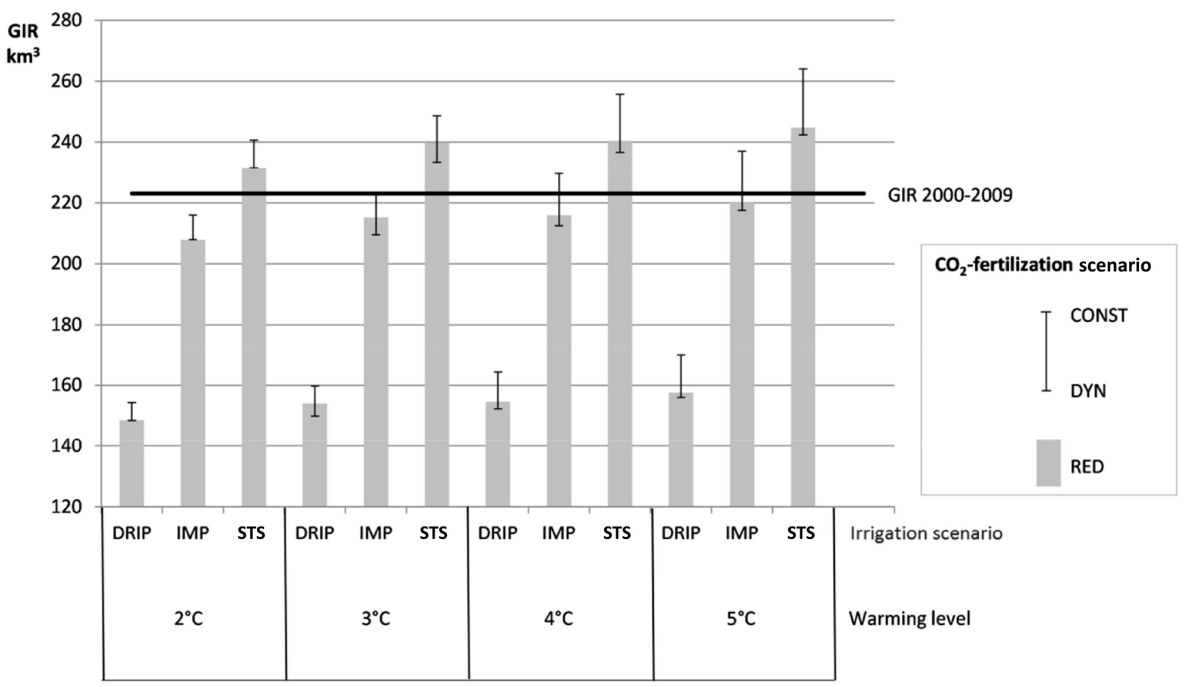

Figure 3. Median (19 GCMs) of gross irrigation water requirements (GIR) for four warming levels, three irrigation scenarios (STS, IMP, DRIP) and three $\mathrm{CO}_{2}$ scenarios (column represents RED and whiskers represent DYN and CONST). The period 2080-2090 for the whole Mediterranean region is shown. Note that the $x$ axis starts at $120 \mathrm{~km}^{3}$.

age over GCMs, which shows slightly higher values than the median (data not shown), demonstrating that results are very robust.

GIR in 2080-2090 will strongly depend on the irrigation technology used by the farmers and on the efficiency of the nation's conveyance systems (pipelines or open channels). Figure 3 shows that this factor may have a larger influence than the strength of warming and the effect of higher $\mathrm{CO}_{2}$ concentrations in the atmosphere (within every warming level, note the large differences between the different irrigation scenarios). Also, regardless of the warming level and the effect of $\mathrm{CO}_{2}$ fertilization, strongly improving irrigation technologies and irrigation water conveyance (DRIP) until the end of the century would have the potential of saving around $30 \%$ of water (compare bars from DRIP and the solid, black line in Fig. 3).

Interestingly, the results of a limited improvement in irrigation technologies and irrigation water conveyance (IMP) are heterogeneous. For a $2{ }^{\circ} \mathrm{C}$ global warming, total withdrawal for irrigation is lower than current values. For a $3{ }^{\circ} \mathrm{C}$ warming, the negative effects of climate change may counteract the gains achieved through the technological improvements. For 4 and $5{ }^{\circ} \mathrm{C}$ warming, the negative effects of climate change may exceed the savings, depending on the actual effect of $\mathrm{CO}_{2}$ fertilization (Fig. 3).

Note that the RED scenario does not always make up the same proportion of CONST and DYN since the implementation of this scenario (see Sect. 2) and the non-linear trajectory of $\mathrm{CO}_{2}$ concentrations as shown in Fig. S2 made it possible to take a high diversity in the combination of the $\mathrm{CO}_{2}$-fertilization effect and warming levels into account. For example, for $2{ }^{\circ} \mathrm{C}$ warming, the $\mathrm{CO}_{2}$ fertilization in DYN and
RED is assumed to be equal, while it separates for higher warming levels (see Fig. S2 for more details).

Souissi et al. (2013) compiled data from various sources using the database of the Blue Plan. They showed estimates of irrigation water use for 2025 in the range of 157 to $212 \mathrm{~km}^{3}$ (compared to $181 \mathrm{~km}^{3}$ in 2005), depending on the scenario (sustainable development in relation to water resource policies and business as usual). The values are naturally lower than ours (Fig. 3), very possibly due to the shorter time frame, but they show that both increases in irrigation water requirements and potential savings in irrigation water are possible depending on the scenario chosen. This is in good agreement with our results.

The results shown in Fig. 3 represent medians and do not show the spread of results from different GCMs. Figure 4 shows for which areas there is a high agreement in NIR results, even using different GCMs as inputs. Under low warming and DYN, most of GCMs compute that the Mediterranean agricultural plants would need slightly less water than today. However, 60 to $80 \%$ of the GCMs also agree on increases in NIR of 15 to $45 \%$ for some French regions (Fig. 4, upper left panel). With increasing warming, and even taking into account some realization of the $\mathrm{CO}_{2}$-fertilization effect (RED), increases in NIR between 15 and $45 \%$ spread to the rest of the Mediterranean region. The GCM agreement under $4{ }^{\circ} \mathrm{C}$ (RED) is generally lower than for 2,3 and $5{ }^{\circ} \mathrm{C}$ warming but still robust for large areas in Spain and Algeria (Fig. 4). High warming and excluding the $\mathrm{CO}_{2}$-fertilization effect yields very high GCM agreement on important NIR increases, especially strong (> 80\%) in central France (Fig. 4, lower right panel).

Figure 2c in Konzmann et al. (2013), calculated for 19 GCMs, the SRES (Special Report Emissions Sce- 

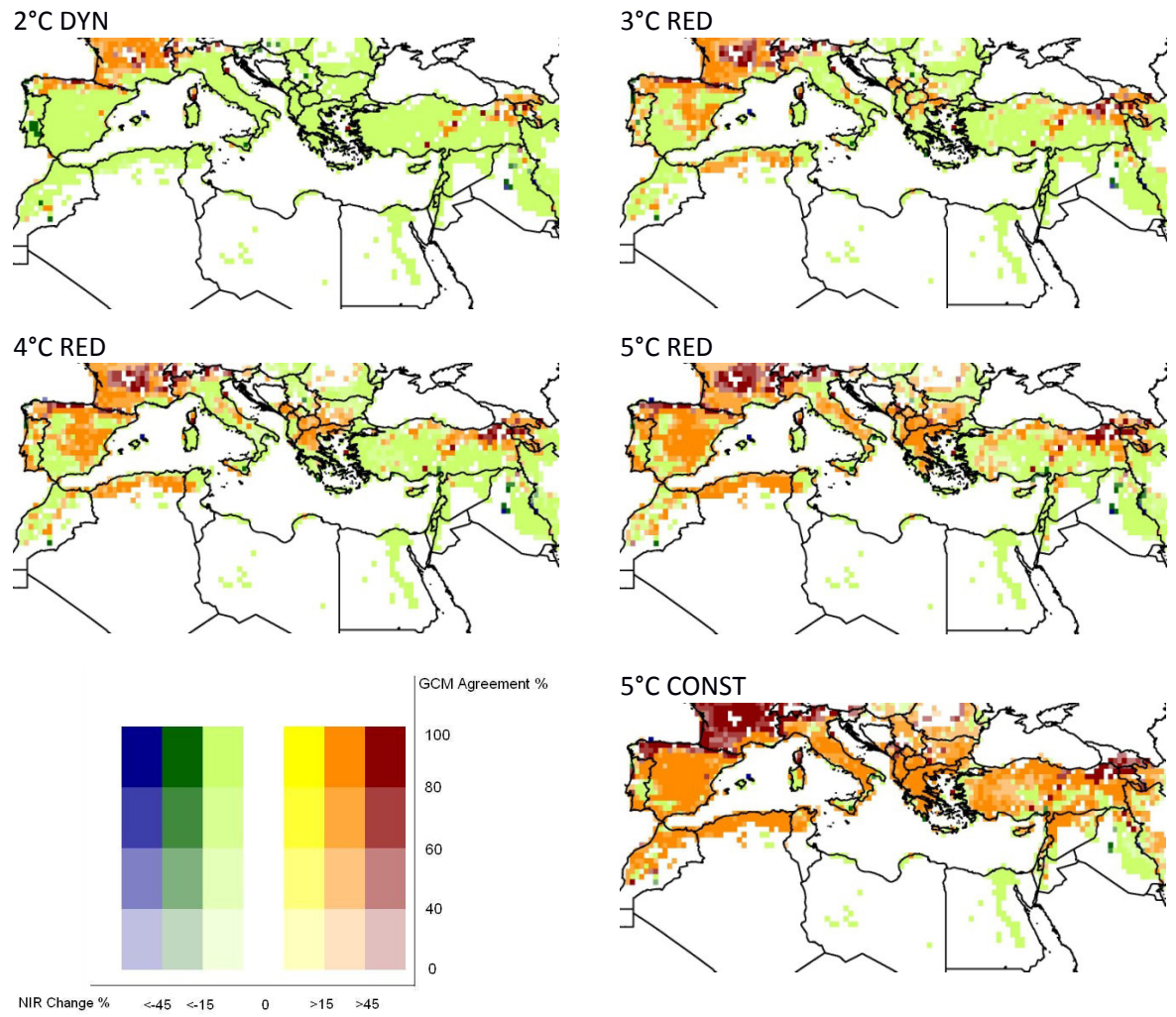

Figure 4. Change in area net irrigation water requirements (NIR) from 2000-2009 to 2080-2090 and GCM agreement (saturation) for 2 to $5{ }^{\circ} \mathrm{C}$ warming combined with different $\mathrm{CO}_{2}$ scenarios. See the Supplement (Fig. S6) for all scenarios arranged according to warming level.

nario) A2 (warming between 2 and $5.4{ }^{\circ} \mathrm{C}$ globally) and constant $\mathrm{CO}_{2}$ concentrations by the 2080 s, show similar patterns to our Fig. 4 (lowest panel), confirming robust, generalized increases in the Mediterranean region, except for Egypt. Moreover, Haddeland et al. (2013) found comparable results, with increases in potential irrigation water consumption with increasing global mean temperature for Spain, Portugal and France. Tables 5 and 6 in the study of Fischer et al. (2007) presented net irrigation water requirements aggregated for regions for two GCMs (with SRES A2 and B1) by the end of the century and taking into account the $\mathrm{CO}_{2}$-fertilization effect. They agree with our results in two points: first, regarding stronger increases in net irrigation requirements with unmitigated climate change and, second, regarding stronger effect for western and southern Europe than for the Middle East and northern Africa.

All the changes shown in Fig. 4 are the result of complex interactions between a region's management intensity, the chosen mix of crops, the climate forcing as well as changes in physiological plant responses (e.g. in the transpiration) and agronomic changes, such as length and beginning of growing period and yields. Figure S7 gives an overview of the influence of decreasing precipitation in this signal. With some exceptions in Libya, Italy and the Balkans, the ensemble median shows that precipitation decreases with increas- ing warming, especially in the northern and eastern Mediterranean for $>2{ }^{\circ} \mathrm{C}$ global warming. Despite this, the physiological changes (especially yield reduction due to shorter growing periods) seem to counteract precipitation decreases in Turkey, the eastern Mediterranean and Egypt, yielding reductions in NIR for global warming levels $<4{ }^{\circ} \mathrm{C}$ (Fig. 4). Section 3.4 gives some insights into this.

\subsection{Population change may aggravate the water situation}

Since some decisions and adaptation measures are taken in supranational institutions, for example at the levels of the European Union or the Arab Maghreb Union, we here show results aggregated according to regions (northern, eastern, and southern Mediterranean; the eastern Mediterranean includes the area from Turkey to Israel and Jordan). Figure 5 shows an overview of future water withdrawal per region, taking climate change, $\mathrm{CO}_{2}$ fertilization, technology improvements in irrigation systems and population change into account. The eastern Mediterranean is today the highest water extractor, followed by the northern Mediterranean, and with a smaller difference, by the southern Mediterranean (red lines Fig. 5).

Climate change alone (without population change, $\mathrm{CO}_{2}$ fertilization and transformation of irrigation systems) may increase gross irrigation water requirements 28,16 and $11 \%$ 

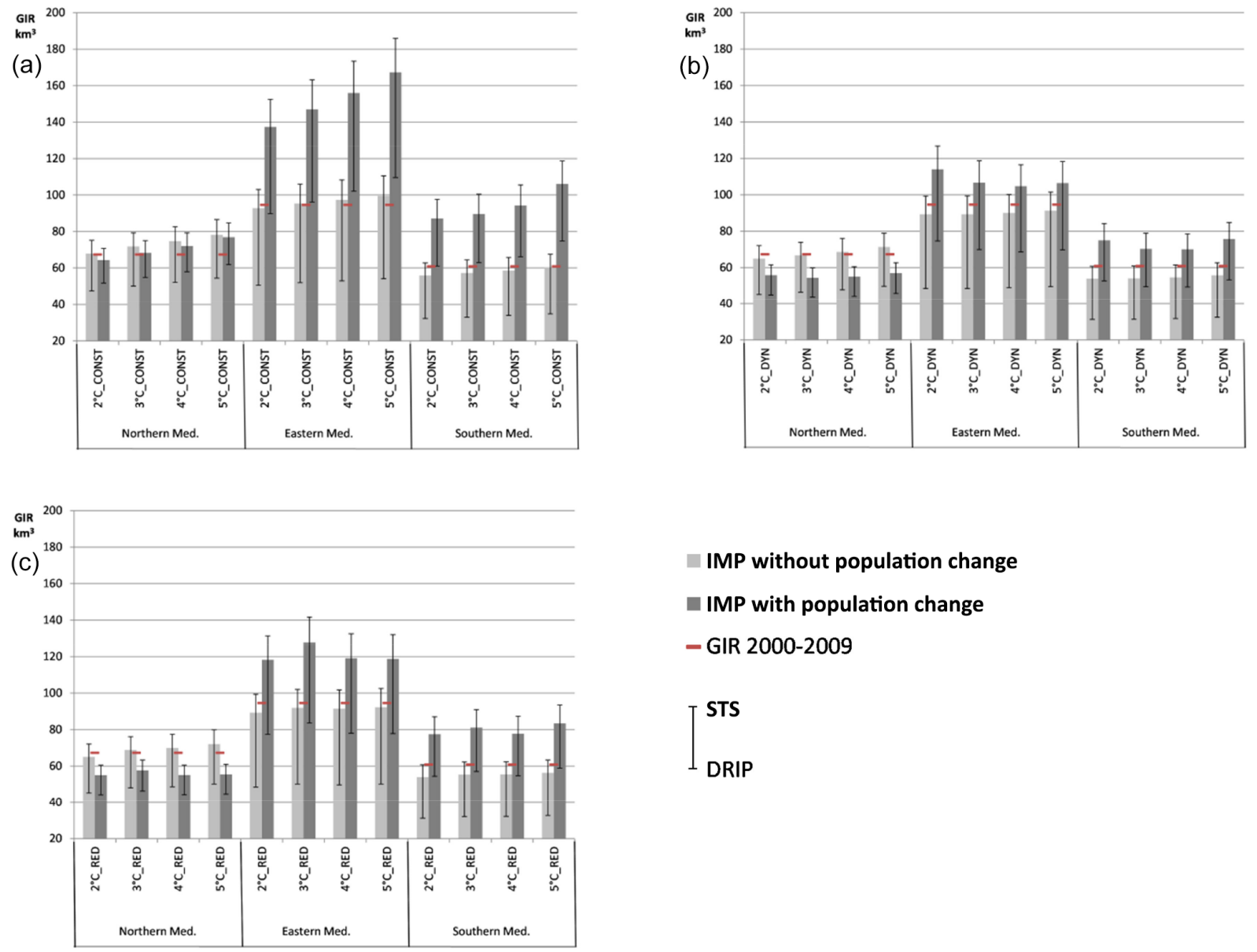

Figure 5. Regional gross irrigation water requirements (GIR) for the CONST (a), DYN (b) and RED (c) $\mathrm{CO}_{2}$-fertilization scenarios, as median of 19 GCMs for the period 2080-2090, for different combinations of warming levels ( $x$ axis), different irrigation scenarios (bars represent the IMP scenarios; whiskers represent the STS and DRIP scenario), and with or without consideration of demographic change (light grey bars: without population change; dark grey bars: with population change). Current regional gross irrigation water requirement is represented by the red lines. Note that the $x$ axis starts at $20 \mathrm{~km}^{3}$.

in the northern, eastern and southern Mediterranean respectively (Fig. 5a). Full realization of the $\mathrm{CO}_{2}$-fertilization effect may decrease these numbers to 17,7 and $3 \%$ (Fig. 5b).

Population growth in combination with stagnation in irrigation technologies, strong climate change and the impossibility of realizing the $\mathrm{CO}_{2}$-fertilization effect may drive GIR up to 185 and $118 \mathrm{~km}^{3}$ in the in the eastern and southern Mediterranean, respectively (Fig. 5a). This would mean almost a doubling of current GIR in both regions ( 95\% increase in both regions). In the northern Mediterranean, taking population change into account eases the situation slightly since the population is expected to decrease in this region. However, GIR still increase by around $25 \%$ because the climate change effect offsets the reduction in GIR due to population decrease.

Improving irrigation technology and the efficiency of irrigation systems has a large water saving potential, especially in the eastern Mediterranean (Fig. 5). However, it can compensate for population growth and climate change only when combined with some degree of $\mathrm{CO}_{2}$-fertilization effect. Looking at the most optimistic $\mathrm{CO}_{2}$-fertilization scenario (DYN) in the eastern and southern Mediterranean, only the DRIP scenario delivers lower GIR than today, when increases due to population and climate change are taken into account (IMP is always above the red lines in Fig. 5b).

Comparing the red lines with the bars or lower whiskers in Fig. 5a shows situations where the effects of climate and population change may compensate for the water savings achieved through improvement and optimization of irrigation and conveyance systems: climate change would compensate for gains through IMP (DRIP) in the northern (eastern) Mediterranean at $3{ }^{\circ} \mathrm{C}$ global warming if $\mathrm{CO}_{2}$ fertilization does not take place (Fig. 5a). Even with some degree of $\mathrm{CO}_{2}$ fertilization, the eastern and southern Mediterranean would need more water than today already at $2{ }^{\circ} \mathrm{C}$ global warming if irrigation technology follows the IMP scenario. 
Adding up the different values for the subregion yields the magnitude of the influence of population change on total GIR: without changes in irrigation systems and conveyance, the Mediterranean region may face increases in NIR of between 22 and $74 \%\left(2{ }^{\circ} \mathrm{C}\right.$ global warming combined with DYN and $5{ }^{\circ} \mathrm{C}$ combined with CONST, respectively).

To summarize, assuming that (a) population change will take place, (b) all Mediterranean regions can afford some degree of modernization of irrigation and conveyance systems (IMP), and (c) $\mathrm{CO}_{2}$ fertilization will happen to some degree but nutrient limitations and other co-dependencies with other production factors will limit its positive effects (RED), the northern Mediterranean will need less water than today and the eastern and southern Mediterranean will need around $35 \%$ more water than today, with the highest values under 3 and $5{ }^{\circ} \mathrm{C}$ global warming, respectively.

There is a general lack of analyses from other studies that can be compared with this section, but our results are in line with some global studies that detected a strong influence of population growth on other water-related issues, for example water scarcity indicators (e.g. Vörösmarty et al., 2000; Schewe et al., 2013).

The results presented so far give an overview when considering all agricultural products together. However, different crops present contrasting patterns of change, as shown in the next section.

\subsection{Agricultural trees affected the most}

Figure 6 presents a summary of crop-disaggregated results for NIR change under different warming levels in the DYN and CONST $\mathrm{CO}_{2}$-fertilization scenario (see the RED scenario in Fig. S8). Most of the crops will need more water per area under climate change, even if the full $\mathrm{CO}_{2}$-fertilization effect is taken into account (Fig. 6a). Grapes are the crop affected most strongly with increases of up to $30 \%$ in the $5{ }^{\circ} \mathrm{C}$ warming trajectory (DYN). Also, all other agricultural trees, especially olives, nut trees, cotton and fruit trees, show high increases; this is of particular concern since they are already major water consumers today (compare Fig. 2a). For $2{ }^{\circ} \mathrm{C}$ warming, increases are mainly limited to below $\sim 8 \%$, but already at $3{ }^{\circ} \mathrm{C}$ warming, cotton, orchards and grapes are pushed above $\sim 10 \%$ increases. The second most strongly affected group of crops is the $\mathrm{C} 4$ crops (maize and sugar cane). Since these crops already have a high water use efficiency, gains through $\mathrm{CO}_{2}$ fertilization are very limited and, thus, NIR increase between 7 and $9 \%$ in the $5{ }^{\circ} \mathrm{C}$ warming trajectory. Groundnuts and rice are less strongly affected, but the areas of these two are very small in the Mediterranean region. The increases are much stronger when considering that the $\mathrm{CO}_{2}$-fertilization effect may not be realized: already at $2{ }^{\circ} \mathrm{C}$ warming NIR increases are as high as $13 \%$ (compare Fig. 6b).

The NIR of some C3 annual crops (mainly food and oil crops) could decrease with increasing warming along with the full $\mathrm{CO}_{2}$-fertilization effect. The NIR reduction tends to saturate with increasing warming (Fig. 6a). Observing these crops in Fig. 6b leads to the conclusion that the NIR decreases are due to the $\mathrm{CO}_{2}$-fertilization effect, i.e. in the case of the realization of this effect not being possible, most $\mathrm{C} 3$ crops would face NIR increases.

The patterns observed in Fig. 6 are the results of complex, interlinked effect chains. Climatic variables and $\mathrm{CO}_{2}$ concentrations affect irrigation requirements directly, for example through the modification of soil evaporation and interception via the modification of the atmospheric demand (potential evaporation). Climate change also affects irrigation requirements via indirect impacts on growing period length, sowing dates and, most importantly, agricultural yields (Fader et al., 2010). Figure 7 sheds light on this topic leading to two main conclusions.

First, the reduction in NIR of most $\mathrm{C} 3$ crops under the full $\mathrm{CO}_{2}$-fertilization effect seems to be produced by a predominance of higher water productivity (lower transpiration) over a shortening of the growing period and lower yield. The opposite seems to be true for perennial crops and $\mathrm{C} 4$ annual crops, where the stimulation of photosynthesis (and higher biomass production), the lengthening of growing periods and the positive changes in potential evapotranspiration seems to offset the reduction in transpiration due to shorter opening times of stomata (compare Figs. 7a and 6a). These crops have both yield and NIR increases, with yield increases being stronger.

Second, yield increases peak for many $\mathrm{C} 3$ food crops at a $3{ }^{\circ} \mathrm{C}$ increase, while yield increases in fruit trees peak at a $4^{\circ} \mathrm{C}$ or even $5^{\circ} \mathrm{C}$ increase (Fig. 7a). Most importantly, however, yield increases and the location of the yield peak depend on the realization of the $\mathrm{CO}_{2}$-fertilization effect (Fig. 7b). The yield of many important Mediterranean crops and crop classes like olives, non-citrus orchards and vegetables will decrease already at low warming if $\mathrm{CO}_{2}$-fertilization effect does not take place. Yield decreases and increases can be minimized and maximized, respectively, by limiting warming to $2{ }^{\circ} \mathrm{C}$ in the case of other limiting factors threatening the realization of the $\mathrm{CO}_{2}$-fertilization effect (Fig. 7b).

These results are in good agreement with some detailed studies on specific crops. For example, Voloudakis et al. (2015) projected yield increases for cotton in Greece with warming between 2 and $4{ }^{\circ} \mathrm{C}$ using the AQUACROP model and taking the $\mathrm{CO}_{2}$-fertilization effect into account. Tanasijevic et al. (2014) projected a $18.5 \%$ increase in irrigation water requirements of olive trees in the Mediterranean region for 2050. Saadi et al. (2015) projected for 2050 a decrease in irrigation water requirements of wheat by $11 \%$ in the Mediterranean region.

\subsection{Water scarcity may constrain future irrigation}

This section closes the results section by relating the calculated water requirements to the national water availabil- 


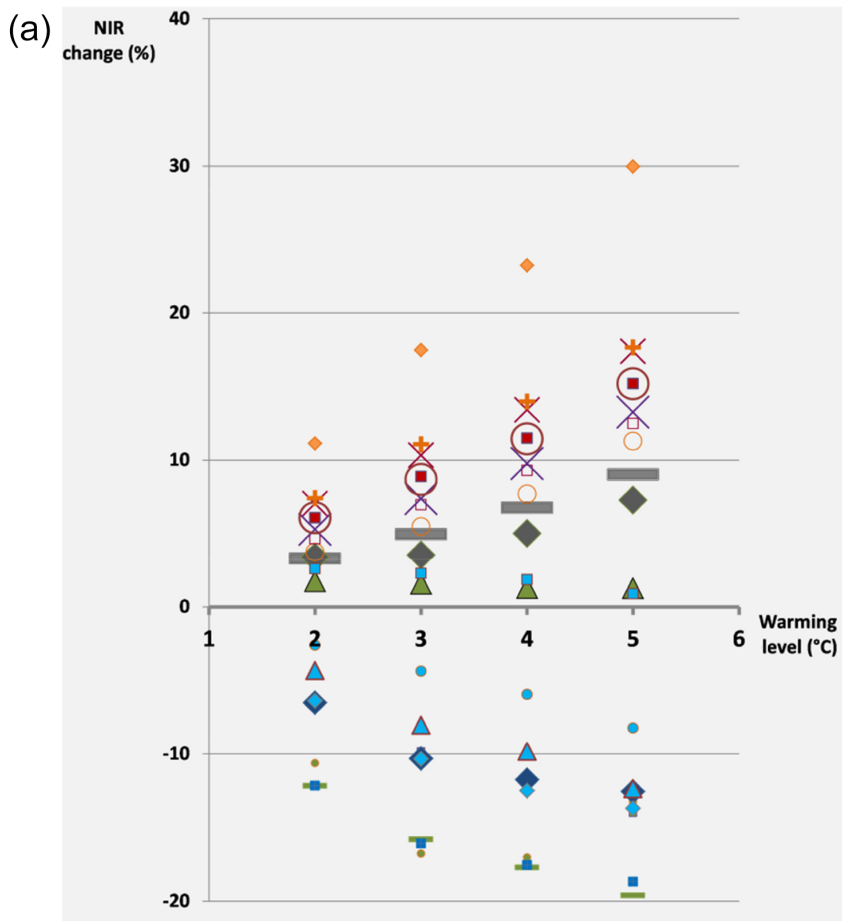

$\underline{\text { C4 Crops }}$

- Sugar Cane

$\checkmark$ Maize

Perennial Crops

Vegetables, Fodder Grass,

Others

$x$ Orchards

$\square$ Citrus

$X$ Date Palm

- Olives

O Nut trees

$\checkmark$ Grapes

+ Cotton

(b) $\underset{\text { change (\%) }}{\mathrm{NIR}}$

C3 crops

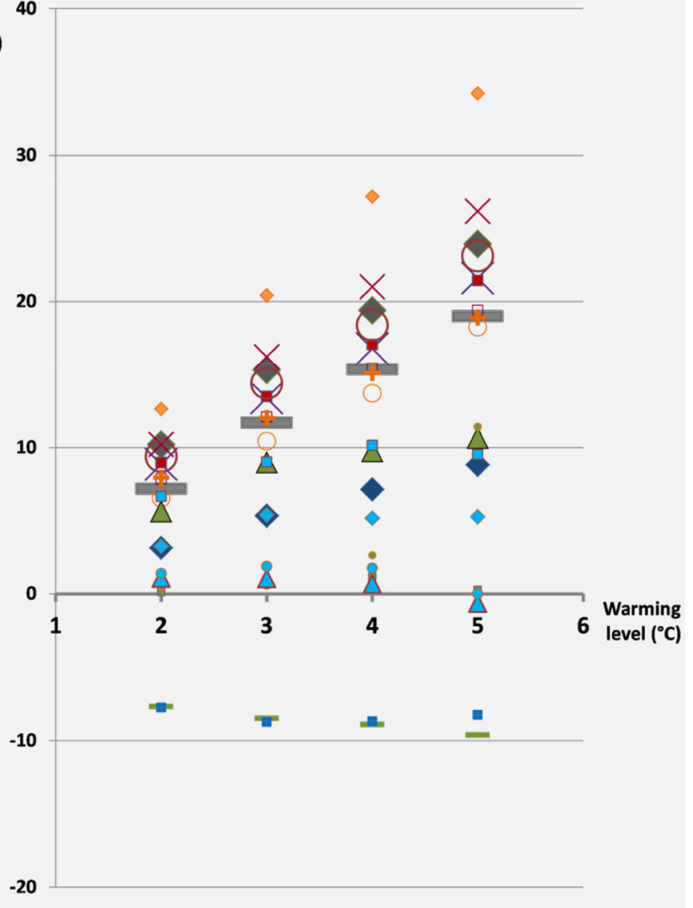

$\triangle$ Groundnuts

- Sunflower

- Soybeans

- Rapeseed

$\checkmark$ Temperate Cereals

$\square$ Rice

$\checkmark$ Tropical Cereals

$\triangle$ Pulses

- Sugar Beet

- Potatoes

Figure 6. Change in per unit of net area irrigation water requirements (NIR) from 2000-2009 to 2080-2090 for different crop classes and the DYN (a) and CONST (b) $\mathrm{CO}_{2}$-fertilization scenario. Negative (positive) values indicate a decrease (increase) in NIR (see Fig. S8 for the RED scenario).

ity scenarios. In the most restricted scenario, i.e. taking into account population growth, $5{ }^{\circ} \mathrm{C}$ global warming, no realization of $\mathrm{CO}_{2}$ fertilization, no improvements in irrigation technology and assuming that every country reserves $30 \%$ of internal surface water for aquatic ecosystems (scenarios GIV_SUS and POL_SUS; see Sect. 2.4), Algeria, Libya, Israel, Jordan, Lebanon, Syria, Serbia, Morocco, Tunisia and Spain would not have enough water for satisfying irrigation 


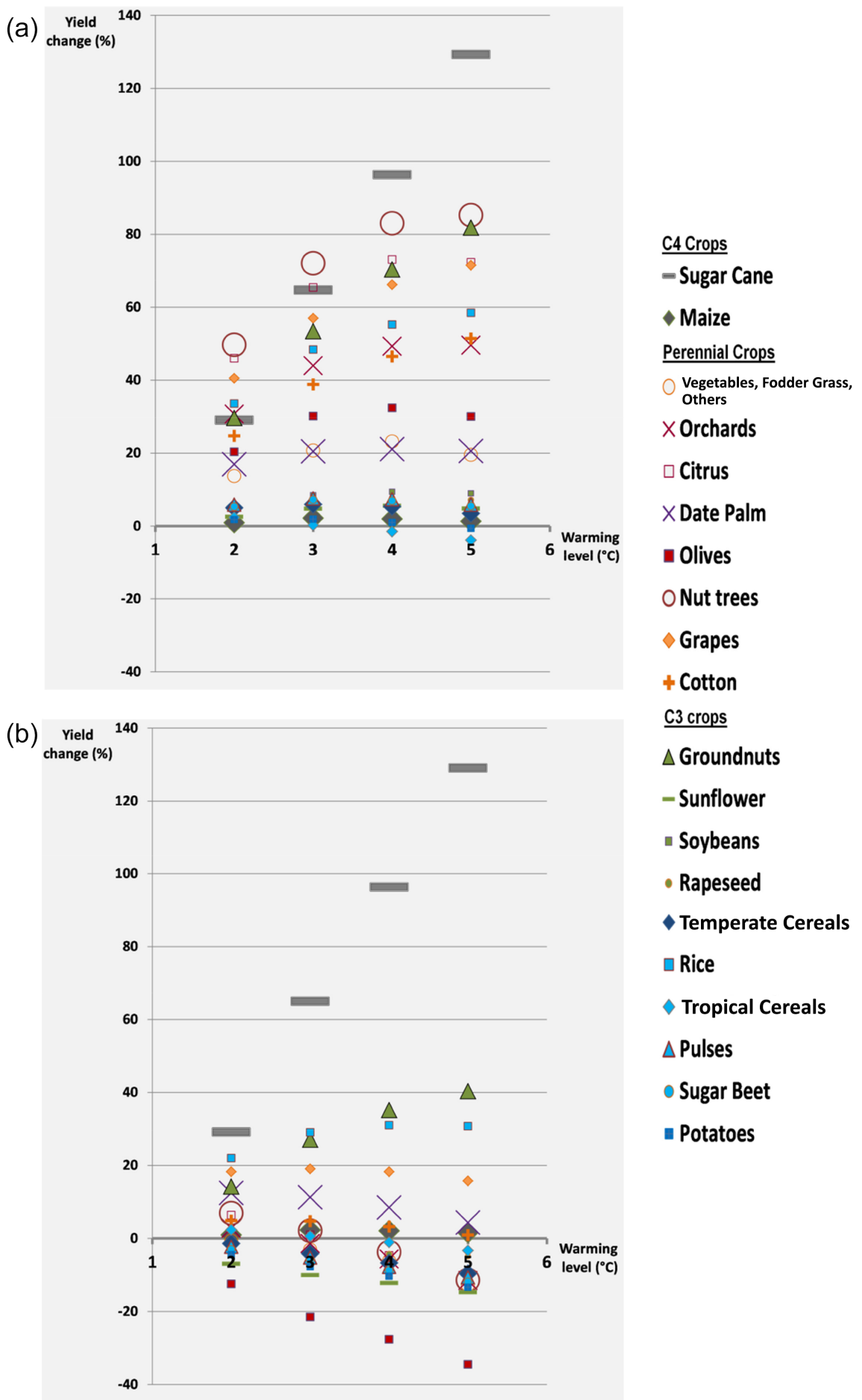

Figure 7. Change in yields from 2000-2009 to 2080-2090 for different crop classes and the DYN (a) and CONST (b) CO 2 -fertilization scenario. Negative (positive) values indicate a decrease (increase) in yields (see Fig. S8 for the RED scenario).

requirements in 2080-2090. This is 10 out of 22 Mediterranean countries. The rest of the Mediterranean countries, mostly situated in the northern Mediterranean, seem to have enough renewable water resources for meeting irrigation requirements in all scenarios.
Six of the countries that cannot meet irrigation water requirements (Algeria, Libya, Israel, Jordan, Syria and Serbia) would not be able to meet them even in the most optimistic scenario of climate change and irrigation technologies (DRIP, $2{ }^{\circ} \mathrm{C}$ warming, DYN $\mathrm{CO}_{2}$-fertilization scenario). 
The other four could potentially meet their irrigation requirements under some scenario combinations. Tunisia and Lebanon could do so by strongly improving irrigation and conveyance systems (DRIP) and ensuring the beneficial effects of $\mathrm{CO}_{2}$ fertilization (DYN or RED) if global warming were limited to $<5^{\circ} \mathrm{C}$ in the case of Tunisia and to $<3{ }^{\circ} \mathrm{C}$ in the case of Lebanon.

Morocco and Spain could meet their requirements already with a medium improvement of irrigation and conveyance systems (IMP) regardless of the warming level or while ensuring that global warming stays below $3{ }^{\circ} \mathrm{C}$.

The comparison between the POL_SUS and GIV_SUS scenarios indicates that Tunisia and Spain have more possibilities of meeting irrigation requirements if they ensure the given external inflow from other countries through international treaties.

The comparison of all these scenarios with the ones without reserving water for environmental flow requirements (POL_UNSUS and GIV_UNSUS; see Sect. 2.4) gives an indication of countries that can be at risk of having tradeoffs between food production and the protection of aquatic ecosystems. This is the case of Algeria, Syria, Serbia, Tunisia, Morocco, Lebanon and Spain. In some scenarios these countries meet irrigation requirements only when not taking environmental flow requirements into account.

Caution is imperative when interpreting these results since they represent an optimistic scenario by comparing irrigation water needs with current water availabilities, i.e. they do not take into account increases in industrial and domestic water use or direct impacts of climate change on the water resources. A global multi-model assessment of climate change impacts on water resources yielded strong and robust reductions in surface runoff for most of the Mediterranean region (Schewe et al., 2013). A second study that takes into account current dams, practices and land use patterns also showed that reduction in surface runoff is likely in this region (Haddeland et al., 2013), but the uncertainty regarding the magnitude remains high. It is worth highlighting that the change in river discharge is especially uncertain among global hydrological models for the eastern and southern Mediterranean (Schewe et al., 2013). In order to test the sensitivity of results to a drastic decrease in water availability, we compared the irrigation requirements and water availability of the most pessimistic and optimistic combinations of scenarios. Assuming $5{ }^{\circ} \mathrm{C}$ warming, CONST $\mathrm{CO}_{2}$-fertilization effect, STS irrigation technologies and $30 \%$ reduction in the POL_SUS water availability scenario (politically secured with reserves for environmental flow requirements), results in terms of the capacity of meeting requirements only change for Egypt and Cyprus. Both countries would be able to meet requirements with POL_SUS water availabilities but not under a reduction of $30 \%$ in POL_SUS water availability. Assuming $2{ }^{\circ} \mathrm{C}$ warming, DYN CO 2 -fertilization effect, DRIP irrigation technologies and a $30 \%$ reduction in the GIV_UNSUS water availability scenario (given availability, no reserves for envi- ronmental flow requirements), the results only change for Algeria and Syria, which would be able to meet requirements with current water availabilities according to GIV_UNSUS but not with a $30 \%$ decrease in GIV_UNSUS.

The figures shown in this section are mainly in line with the multi-model effort of Elliot et al. (2014) and confirm that future irrigation requirements will face water availability constraints, especially in the southern Mediterranean. Also, the study by Fischer et al. (2007), in spite of methodological differences, indicates that the Middle East and northern Africa may be affected by a high water scarcity index (agricultural water withdrawal to internal renewable water resources up to $96 \%$ ) in 2080, designating potential difficulties for meeting future irrigation water requirements. For Europe and Turkey they have a much lower value (up to 10\%), which is also in good agreement with our results.

\section{Conclusions and discussion}

This study systematically assesses how climate change and increases in atmospheric $\mathrm{CO}_{2}$ concentrations may affect irrigation requirements in the Mediterranean region in the context of demographic and technological change. The comparisons with other estimates presented in the results section reveal a strong robustness of our results that allows drawing some conclusions.

1. At present the Mediterranean region could save $35 \%$ of water by implementing more efficient irrigation and conveyance systems. Some countries like Syria, Egypt and Turkey have a higher saving potential than others (e.g. Tunisia, Libya and France).

2. Without the positive effects of higher $\mathrm{CO}_{2}$ concentrations in the atmosphere, a large proportion of climate models gives a robust signal of increasing net irrigation requirements in the Mediterranean region at $3{ }^{\circ} \mathrm{C}$ global warming and above. This is the result of a spatially explicit, complex interplay of modifications in growing periods, potential evapotranspiration, precipitation patterns and physiological responses.

3. Currently some crops, especially sugar cane and agricultural trees, consume on average more irrigation water per hectare than annual crops. Different crops show different magnitudes of changes in net irrigation requirements, the increases being most pronounced in agricultural trees. The $\mathrm{CO}_{2}$-fertilization effect can lower or counteract the increases in NIR of some C3 annual crops.

4. Gross irrigation water requirements may increase or decrease depending on the future efficiency of irrigation and conveyance systems, the effect of population growth on food (and water) demand and the climate change impacts, while the first two seem to have 
the strongest influence. The Mediterranean area as a whole may face an increase in gross irrigation requirements between 4 and $18 \%$ from climate change alone if irrigation systems and conveyance are not improved $\left(2{ }^{\circ} \mathrm{C}\right.$ global warming combined with the full $\mathrm{CO}_{2}$ fertilization effect and $5{ }^{\circ} \mathrm{C}$ global warming combined with no $\mathrm{CO}_{2}$-fertilization effect, respectively). Population growth increases these numbers to 22 and $74 \%$, respectively.

5. Subregional patterns of GIR change are complex and vary depending on the combination of climate change, irrigation technologies and $\mathrm{CO}_{2}$ fertilization. The northern Mediterranean will need less water than today, and the eastern and southern Mediterranean will need around $35 \%$ more water than today, assuming that population growth may increase food demand, that all subregions can afford some degree of modernization of irrigation and conveyance systems (IMP), and that $\mathrm{CO}_{2}$ fertilization will happen to some degree (RED).

6. In some scenarios water scarcity may constrain the supply of the irrigation water needed in future in Algeria, Libya, Israel, Jordan, Lebanon, Syria, Serbia, Morocco, Tunisia and Spain.

\subsection{Similar forcing, heterogeneous implications}

As explained in the introduction, the amount of water needed for agricultural production in the Mediterranean region is a topic of economic and social relevance with political implications. The results of this study show that political incentives for water saving technologies as well as the development of efficient public water conveyance systems may help to reduce water extractions already today but also under future climate change. This is especially true for the eastern Mediterranean (Figs. 2b, 3 and 5).

Taking into account that irrigation water availability may be increasingly limited in the future by competing uses, land use change, and climate change, the Mediterranean region may be very interested in supporting the limitation of climate change to $2{ }^{\circ} \mathrm{C}$ global warming in order to potentially reduce irrigation requirements and require lower investments in irrigation technology and infrastructure. Already at $3{ }^{\circ} \mathrm{C}$ global warming, the investment and incentives needed to compensate for climate change may be much more important than under $2^{\circ} \mathrm{C}$ (Fig. 3).

Climate models deliver a consistent picture in the Mediterranean region: France seems to have the highest risk of suffering from higher irrigation requirements, even at low warming levels but especially pronounced at high warming levels. The agreement of climate models for Spain, Turkey and Greece are shown to be especially strong in the case of the $\mathrm{CO}_{2}$-fertilization effect not being realized (Fig. 4). For these countries, sustainable management of soil nutrients and soil water conservation techniques may help to benefit from the $\mathrm{CO}_{2}$-fertilization effect.

The importance of drivers of change in irrigation requirements differs from region to region. Climate change may be the most threatening factor for the northern Mediterranean, while population change combined with strong water scarcity seem to be the most important detrimental factors in the eastern and southern Mediterranean. Strong technological improvement may compensate for the increases in irrigation requirements due to climate change in the northern Mediterranean. In the eastern and southern Mediterranean a medium improvement of technologies even combined with low warming and a full $\mathrm{CO}_{2}$-fertilization effect would not be enough to avoid increases in gross irrigation water requirements (Fig. 5). And most importantly, these increased irrigation requirements have a high risk of not being met due to water scarcity (Sect. 3.5). In this context, the governments of the southern and eastern Mediterranean may be interested in supporting climate change mitigation along with economic development in order to produce the financial means for virtual water imports, increasing sustainable water supply infrastructure and decreasing the water demand of all sectors.

Improving irrigation technology is not the only way of coping with water scarcity. For example soil water conservation techniques, such as mulching and zero tillage, may help to reduce irrigation requirements, especially in the regions where irrigation is meant to complement rainfall. The influence of these factors is being analysed by a group at the Mediterranean Institute of Marine and Terrestrial Biodiversity and Ecology in order to explore adaptation options under climate change. Switching the type of crops within the agricultural areas may offer another adaptation option to cope with increases in irrigation requirements. Annual crops seem to be less prone to increases in irrigation requirements and decreases in yields than agricultural trees, the relationships between both being complex (Figs. 6 and 7). Given that agricultural trees are an essential part of Mediterranean culture and agriculture, two implications follow: first, governments may be interested in developing plans for protecting and supporting farmers linked to agricultural trees and perennial shrubs; second, research agencies and researchers may be interested in focusing efforts for a better understanding of this kind of trade-offs and assessing the potential for adaptation in more detail.

Another option for several countries is avoiding a direct relationship between food demand and population growth by increasing virtual water imports and improving agricultural management (additionally to improvements in irrigation technology) (see, e.g., Fader et al., 2013). These are much discussed topics with political, environmental and economic implications, and both the topics and implications need careful consideration in order to avoid self-induced food security risks. Other countries with a high risk of depleting the water needed by aquatic ecosystems, as is the case in Algeria, Serbia, Tunisia, Morocco, Lebanon and Spain (Sect. 3.5), may 
want to combine different strategies: first, supporting climate change mitigation; second, changing their land use strategies, including changing crops; and third, developing monitoring systems that allow keeping control of water extractions that are to the detriment of aquatic ecosystems.

Finally, collaboration, know-how transfer and cooperation in mitigation and adaptation, including a coordinated Mediterranean negotiation at the Conference of the Parties linked to the United Nations Framework Convention on Climate Change, may help the region to tackle the challenges described. As described in the next section, this has to go hand in hand with future research efforts aimed at both reducing the uncertainty of results and improving the understanding of the functioning of the Earth system as a managed space.

\subsection{Strengths, weaknesses and perspectives for future research}

This section offers an overview on the strengths and weaknesses of the present study and ideas for improving research on this topic in future.

One of the strengths of this study is the dynamic simulation of growing periods, sowing dates, crop varieties, and phenology in agricultural trees. This allows for more realistic estimates of future irrigation requirements since some adaptation options and changes in the length of growing periods are already included in future simulations. However, the possibility of adapting through deficit irrigation (fulfilling only a part of vegetation water needs and thus lowering future irrigation water needs) was not taken into account. Challenges regarding the implementation of deficit irrigation are not only the complexity and non-linearity of the physiological response to low levels of water deficit but also that these responses vary largely depending on the growth stage at which the water deficit is induced (FAO, 2002). Jägermeyr et al. (2015) recently made advances related to this topic and, in a sensitivity analysis, found that $\mathrm{C} 4$ plants can tolerate more water deficit in the soil than $\mathrm{C} 3$ plants. In order to give an indication of the sensitivity of our results to the implementation of deficit irrigation, we performed an additional run for the present time lowering the threshold of soil water deficit at which irrigation happens in LPJmL (from $<90$ to $<70 \%$ ). Irrigation water withdrawal was around $8 \%$ lower in this run than in the standard run, i.e. water savings of $20 \mathrm{~km}^{3}$ for the entire region were achieved. However, yields did not stay unchanged: while annual crops were comparatively insensitive (yield decreases $<1 \%$ ), the yield of vegetables and fodder grasses decreased by around $4 \%$ and the yield of agricultural trees by around $8 \%$, with the highest values in non-citrus orchards and for citrus trees $(\sim 11 \%)$. This experiment highlights the importance of including agricultural trees in studies focused on water savings through deficit irrigation.

The present study is focused on the water needs for keeping production and cultivation mainly on current irrigated areas. Land use change and irrigation expansion were considered in a simplified way through a linear relationship between food demand and demographic change. Future diet changes with associated land use shifts towards more meat and water-intensive products were not taken into account. There is a general lack of information on these issues, especially on crop-specific land use patterns in the future, and this is the reason why this could not be taken into account. However, a recent global estimate yields a potential for compensating for between 12 and $57 \%$ of productivity loss caused by climate change in around 2090 (RCP8.5) by the expansion of irrigation (Elliot et al., 2014). Nevertheless, further research that includes various land use scenarios according to different drivers, taking into account groundwater dynamics, specifically including regional crops, and coupling water resources and vegetation growth is urgently needed for the Mediterranean area and will be part of future research efforts.

In the modelling framework used for simulating irrigation requirements plant growth is influenced by parameters representing different components of current agricultural management intensity (see also Fader et al., 2010). Assuming that nutrient deficits, soil erosion and salinization may limit the realization of the $\mathrm{CO}_{2}$-fertilization effect, this study deals with the linked uncertainties by analysing different scenarios of the $\mathrm{CO}_{2}$-fertilization effect, and, for the first time, including a scenario of a reduced $\mathrm{CO}_{2}$-fertilization effect. This is one of the strengths of this study but indicates the necessity of further model development towards a process-based representation of the phosphorus, potassium and nitrogen cycles coupled with the photosynthesis and respiration routines (see, e.g., Soussana et al., 2010). A research group in the Potsdam Institute for Climate Impact Research is working on tackling the implementation of the nitrogen cycle, which will also open up the possibility of better representing alternative farming practices. Also, one has to keep in mind that crops grown under increased $\mathrm{CO}_{2}$ concentrations may have a lower nutritional value and the realization of the $\mathrm{CO}_{2}$-fertilization effect may require large efforts for managing efficiently all production inputs, which may represent an important challenge (Porter et al., 2014; DaMatta et al., 2010).

Our research shows large adaptive potential through the implementation of drip irrigation and efficient conveyance systems (pressurized pipelines). High-tech irrigation systems may offer advantages such as the conservation of fertilizers, reduction of water logging and higher yields due to high uniformity. However, less efficient irrigation and conveyance systems with high percolation and infiltration rates may have benefits, for example groundwater recharge, salt leaching, crop cooling, frost protection and high return flows in downstream areas, supporting food production and food security (e.g. Bastiaanssen et al., 2007). Thus, in order to avoid conflicts between up- and downstream water users, efforts must be put into local solutions based on the integral management of water resources at the watershed level. In addition to this point, drip and high-tech irrigation systems require 
high investment and high maintenance from qualified technicians for avoiding problems related to clogging and salinization (Belhouchette et al., 2012). Also, farmers may use the saved water for planting higher-value crops or base their crop choices on water productivity rather than on total water consumption. More research on the socioeconomic and cultural constraints of the implementation of efficient irrigation systems and on complementary measures like climatesmart agriculture, planting drought-resistant crops, rainwater harvesting and the diversification of production systems is needed to bring these conclusions to the fields (Pedrick, 2012; Blinda, 2012).

When analysing the water saving potential of more efficient irrigation systems and water conveyance infrastructure, we disregard the fact that more efficient irrigation systems usually require more energy (and have higher investment costs). If this additional energy was to be provided by burning fossil fuels, a positive feedback would be created: climate change increases irrigation requirements, which lead to technological transformation, which in turn leads to higher energy demand and finally to more fossil fuel burning and more climate change. Even if this omission was intentional in order to assess non-energy-limited potential for adaptation, the non-fossil-fuel possibilities for supplying the energy needed for more efficient irrigation systems should be at the core of future research efforts.

The analysis of water scarcity carried out in the present study is a way of pointing out which countries could potentially face water shortage with regard to future irrigation. Table S1 in the Supplement summarizes the characteristics, advantages and disadvantages of this approach. On the one hand these results are based on a rather optimistic scenario by comparing potential (not limited) irrigation water needs with current, renewable water availabilities at national level, i.e. they may mask subnational, seasonal patterns of water stress and they do not take into account future changes in industrial and domestic water use as well as direct impacts of climate change on the water resources. On the other hand, they may represent a pessimistic scenario by not considering fossil groundwater availability, desalination potential and the potential for water recycling and reuse. The first point is justified by the continuously dropping groundwater levels (e.g. Wada et al., 2010), which may lead to water depletion in the near future. Regarding desalinization, water recycling and reuse, these processes are very energy and cost intensive at the moment (Elimelech and Phillip, 2011; Blinda, 2012), making their future development very uncertain. As important all these factors are, there are unknown variables and a general lack of data that constrain large improvements in the approach applied in the present study. Interdisciplinary efforts aimed at the development of socioeconomic, technological and political scenarios that can be integrated with studies on the impact of climate change on water resources are urgently needed to fill these gaps.
The model used for this study (LPJmL) includes a dynamic coupling of photosynthesis, water stress and $\mathrm{CO}_{2}$ uptake (Gerten et al., 2004) and was recently further developed and successfully tested for including the most important crops in the Mediterranean region (Fader et al., 2015). Thus, LPJmL is probably the most complete, mechanistic agroecosystem model for the Mediterranean region at present. However, this study is focussed on potential net and gross irrigation requirements, i.e. we assumed that irrigation needs are always met and, as a posterior step, we compare these needs with water availabilities. This implicitly constrains the assessment of production increases in water-scarce regions through the supply of water saved in other regions as well as the assessment of "more crop per drop" potential. The study of Jägermeyr et al. (2015) looks into these issues for the present time and argues that transpiration and non-beneficial water consumption are not as closely related as previously assumed, i.e. it states that there is a large potential for producing more food with less water. Further research on the dynamics of this relationship under climate change is greatly needed to complement our findings.

In summary, the present study offers new, detailed evidence about potential increases in water needs and possible water shortages for irrigation due to future climate and demographic change. These results are complemented by a comprehensive analysis on how Mediterranean societies could adapt to this situation by improving irrigation and conveyance systems.

\section{The Supplement related to this article is available online at doi:10.5194/hess-20-953-2016-supplement.}

Acknowledgements. This work is a contribution to the Labex OTMed (no. ANR-11-LABX-0061) funded by the French Government "Investissements d'Avenir" program of the French National Research Agency (ANR) through the A*MIDEX project (no. ANR11-IDEX-0001-02).

We thank the LPJmL group at the Potsdam Institute for Climate Impact Research for the provision of climate inputs for LPJmL.

Edited by: L. Wang

\section{References}

Ackerman, F. and Stanton, E. A.: Climate Impacts on Agriculture: A Challenge to Complacency? Global Development and Environment Institute, Tufts University, Medford, USA, 2013.

Ainsworth, E. A., Leakey, A. D. B., Ort, D. R., and Long, S. P.: FACE-ing the Facts: Inconsistencies and Interdependence among Field, Chamber, and Modeling Studies of Elevated $\mathrm{CO}_{2}$ Impacts on Crop Yield and Food Supply, New Phytol., 179, 5-9, 2008.

AIRMF: L'agriculture irriguée méditerranéenne, Une source de richesse au coeur des enjeux du développement durable, Syn- 
thèse de l'étude sur le poids économique, social et environnemental de l'irrigation dans les régions méditerranéennes françaises, Chambre Régionale d'agriculture du LanguedocRoussillon, Lattes, France, 2009.

Bastiaanssen, W. G. M., Allen, R. G., Droogers, P., D’Urso, G., and Steduto, P.: Twenty-five years modelling irrigated and drained soils: state of the art, Agr. Water Manage., 92, 111-125, 2007.

Belhouchette, H., Blanco, M., and Flichman, G.: Sustainability of irrigated farming systems in a Tunisian region: a recursive stochastic programming analysis, Comput. Elect. Agr., 86, 100$110,2012$.

Blinda, M.: Water efficiency. More efficient water use in the Mediterranean. Paper 14. Plan Bleu. 41 pp., Valbonne, France, 2012.

Bondeau, A., Smith, P., Zaehle, S., Schaphoff, S., Lucht, W., Cramer, W., Gerten, D., Lotze-Campen, H., Müller, C., Reichstein, M., and Smith, B.: Modelling the role of agriculture for the 20th century global terrestrial carbon balance, Global Change Biol., 13, 1-28, 2007.

DaMatta, F. M., Grandis, A., Arenque, B. C., and Buckeridge, M. S.: Impacts of climate changes on crop physiology and food quality, Food Res. Int., 43, 1814-1823, doi:10.1016/j.foodres.2009.11.001, 2010.

Doell, P. and Siebert, S.: Global modeling of irrigation water requirements, Water Resour. Res., 38, 1037, doi:10.1029/2001WR000355, 2002.

Elimelech, M. and Phillip, W. A.: The Future of Seawater Desalination: Energy, Technology, and the Environment, Science, 333, 712-717, doi:10.1126/science.1200488, 2011.

Elliott J., Deryng, D., Müller, C., Frieler, K., Konzmann, M., Gerten, D., Glotter, M., Flörke, M., Wada, Y., Best, N., Eisner, S., Fekete, B. M., Folberth, C., Foster, I., Gosling, S. N., Haddeland, I., Khabarov, N., Ludwig, F., Masaki, Y., Olin, S., Rosenzweig, C., Ruane, A. C., Satoh, Y., Schmid, E., Stacke, T., Tang, Q., and Wisser, D.: Constraints and potentials of future irrigation water availability on agricultural production under climate change, P. Natl. Acad. Sci. USA, 111, 3239-3244, doi:10.1073/pnas.1222474110, 2014.

EU - Council of the European Union: Energy efficiency and renewable energies, Presidency Conclusions of the Brussels European Council 8/9 March 2007), EU, Brussels, 20-22, 2007.

Fader, M., Rost, S., Müller, C., Bondeau, A., and Gerten, D.: Virtual water content of temperate cereals and maize: Present and potential future patterns, J. Hydrol., 384, 218-231, 2010.

Fader, M., Gerten, D., Krause, M., Lucht, W., and Cramer, W.: Spatial decoupling of agricultural production and consumption: quantifying dependence of countries on food imports due to domestic land and water constraints, Environ. Res. Lett., 8, 014046 , doi:10.1088/1748-9326/8/1/014046, 2013.

Fader, M., von Bloh, W., Shi, S., Bondeau, A., and Cramer, W.: Modelling Mediterranean agro-ecosystems by including agricultural trees in the LPJmL model, Geosci. Model Dev., 8, 35453561, doi:10.5194/gmd-8-3545-2015, 2015.

FAO: Chapter 2: Crop water needs, in: Irrigation water management: Irrigation Water Needs, Training manual No. 3, edited by: Brower, C. and Heibloem, M., http://www.fao.org/docrep/ s2022e/s2022e00.htm\#Contents (last access: 1 November 2014), 1986.
FAO: Deficit irrigation practices, FAO water reports 22, Rome, 111 pp., 2002.

FAO: AQUASTAT Database, http://www.fao.org/nr/water/aquastat/ data/query/index.html?lang=en, last access: 1 May 2015.

FAOSTAT: http://faostat.fao.org/site/567/default.aspx\#ancor, last access: 1 Juny 2014.

Faurès, J.-M., Hoogeveen, J., and Bruinsma, J.: The FAO irrigated area forescast for 2030. ftp://ftp.fao.org/agl/aglw/docs/ fauresetalagadir.pdf (last access: 2 January 2015), 2000.

Fischer, G., Tubiello, F. N., van Velthuizen, H., and Wiberg, D. A.: Climate change impacts on irrigation water requirements: Effects of mitigation, 1990-2080, Technol. Forecast. Social Change, 74, 1083-1107, 2007.

Forzieri, G., Feyen, L., Rojas, R., Flörke, M., Wimmer, F., and Bianchi, A.: Ensemble projections of future streamflow droughts in Europe, Hydrol. Earth Syst. Sci., 18, 85-108, doi:10.5194/hess-18-85-2014, 2014.

Gerten, D., Schaphoff, S., Haberlandt, U., Lucht, W., and Sitch, S.: Terrestrial vegetation and water balance. Hydrological evaluation of a dynamic global vegetation model, J. Hydrol., 286, 249-270, 2004.

Haddeland, I., Heinke, J., Biemans, H., Eisner, S., Flörke, M., Hanasaki, N., Konzmann, M., Ludwig, F., Masaki, Y., Schewe, J., Stacke, T., Tessler, Z. D., Wada, Y., and Wisser, D.: Global water resources affected by human interventions and climate change, P. Natl. Acad. Sci. USA, 111, 3251-3256, doi:10.1073/pnas.1222475110, 2013.

Hatfield, J. L., Boote, K. J., Kimball, B. A., Ziska, L. H., Izaurralde, R. C., Ort, D., Thomson, A. M., and Wolfe, D.: Climate Impacts on Agriculture: Implications for Crop Production, Agron. J., 103, 351-370, doi:10.2134/agronj2010.0303, 2011.

Heinke, J., Ostberg, S., Schaphoff, S., Frieler, K., Müller, C., Gerten, D., Meinshausen, M., and Lucht, W.: A new climate dataset for systematic assessments of climate change impacts as a function of global warming, Geosci. Model Dev., 6, 1689-1703, doi:10.5194/gmd-6-1689-2013, 2013.

IPCC: Climate Change 2014: Impacts, Adaptation, and Vulnerability, in: Part A: Global and Sectoral Aspects, Contribution of Working Group II to the Fifth Assessment Report of the Intergovernmental Panel on Climate Change, edited by: Field, C. B., Barros, V. R., Dokken, D. J., Mach, K. J., Mastrandrea, M. D., Bilir, T. E., Chatterjee, M., Ebi, K. L., Estrada, Y. O., Genova, R. C., Girma, B., Kissel, E. S., Levy, A. N., MacCracken, S., Mastrandrea, P. R., and White, L. L., Cambridge University Press, Cambridge, UK and New York, NY, USA, 1132 pp., 2014.

Jägermeyr, J., Gerten, D., Heinke, J., Schaphoff, S., Kummu, M., and Lucht, W.: Water savings potentials of irrigation systems: global simulation of processes and linkages, Hydrol. Earth Syst Sci., 19, 3073-3091, doi:10.5194/hess-19-3073-2015, 2015.

Konzmann, M., Gerten, G., and Heinke, J.: Climate impacts on global irrigation requirements under $19 \mathrm{GCMs}$, simulated with a vegetation and hydrology model, Hydrolog. Sci. J., 58, 88-105, 2013.

Lanquar, R.: Tourism in the Mediterranean: Scenarios up to 2030, MedPro Report WP5, http://aei.pitt.edu/58341/1/MEDPRO_ Report_No_1.pdf (last access: 27 May 2015), 2013.

Lionello, P., Malanotte-Rizzoli, P., Boscolo, R., Alpert, P., Artale, V., Li, L., Luterbacher, J., May, W., Trigo, R., Tsimplis, M., Ulbrich, U., and Xoplaki, E.: The Mediterranean Climate: An 
Overview of the Main Characteristics and Issues, in: Mediterranean Climate Variability, Developments in Earth and Environmental Sciences 4, edited by: Lionello, P., Malanotte-Rizzoli, P., and Boscolo, R., Elsevier, Amsterdam, 2006.

Long, S. P., Ainsworth, E. A., Leakey, A. D. B., Nösberger, J., and Ort, D. R.: Food for Thought: Lower-than-expected Crop Yield Stimulation with Rising CO2 Concentrations, Science, 312, 1918-1921, doi:10.1126/science.1114722, 2006.

Manero, A.: Comparative water management practices in California and Spain. Universitat Politècnica de Catalunya, https: //upcommons.upc.edu/pfc/bitstream/2099.1/6053/8/07.pdf (last access: 5 January 2015), 2008.

Meinshausen, M., Raper, S. C. B., and Wigley, T. M. L.: Emulating coupled atmosphere-ocean and carbon cycle models with a simpler model, MAGICC6 - Part 1: Model description and calibration, Atmos. Chem. Phys., 11, 1417-1456, doi:10.5194/acp11-1417-2011, 2011.

Niang, I., Ruppel, O. C., Abdrabo, M. A., Essel, A., Lennard, C., Padgham, J., and Urquhart, P.: Africa, in: Climate Change 2014: Impacts, Adaptation, and Vulnerability, Part B: Regional Aspects, Contribution of Working Group II to the Fifth Assessment Report of the Intergovernmental Panel on Climate Change, edited by: Barros, V. R., Field, C. B., Dokken, D. J., Mastrandrea, M. D., Mach, K. J., Bilir, T. E., Chatterjee, M., Ebi, K. L., Estrada, Y. O., Genova, R. C., Girma, B., Kissel, E. S., Levy, A. N., MacCracken, S., Mastrandrea, P. R., and White, L. L., Cambridge University Press, Cambridge, UK and New York, NY, USA, 1199-1265, 2014.

Nieto-Romero, M., Oteros-Rozas, E., González, J. A., and MartínLópez, B.: Exploring the knowledge landscape of ecosystem services assessments in Mediterranean agroecosystems: insights for future research, Environ. Sci. Policy, 37, 121-133, 2014.

Pedrick, C.: Strategies for combating climate change in drylands agriculture: Synthesis of dialogues and evidence presented at the International Conference on Food Security in Dry Lands, Doha, Qatar, November, 2012, The International Center for Agricultural Research in the Dry Areas (ICARDA) and CGIAR Research Program on Climate Change, Agriculture and Food Security (CCAFS), Aleppo, Syria and Copenhagen, Denmark, 2012.

Porter, J. R., Liyong, X., Challinor, A., Cochrane, K., Howden, M., Iqbal, M. M., Lobell, D., and Travasso, M. I.: Food Security and Food Production Systems, in: IPCC 2014: Climate Change 2014: Impacts, Adaptation, and Vulnerability, Contribution of Working Group II to the Fifth Assessment Report of the Intergovernmental Panel on Climate Change, Chapter 7, Final Draft, IPCC AR5 WGII, Cambridge University Press, Cambridge, New York, 2014.

Rodríguez-Díaz, J. A. and Topcu, S.: Sustaining Mediterranean irrigated agriculture under a changing climate, Outlook Agricult., 39, N4, doi:10.5367/oa.2010.0018, 2010.

Rodriguez-Diaz, J. A., Weatherhead, E. K., Knox, J. W., and Camacho, E.: Climate change impacts on irrigation water requirements in the Guadalquivir river basin in Spain, Reg. Environ. Change, 7, 149-159, 2007.

Rohwer, J., Gerten, D., and Lucht, W.: Development of functional irrigation types for improved global crop modelling, PIK Report 104, Potsdam Institute for Climate Impact Research, Potsdam, 98 pp., 2006.
Rost, S., Gerten, D., Bondeau, A., Lucht, W., Rohwer, J., and Schaphoff, S.: Agricultural green and blue water consumption and its influence on the global water system, Water Resour. Res., 44, W09405, doi:10.1029/2007WR006331, 2008.

Rudolf, B., Becker, A., Schneider, U., Meyer-Christoffer, A., and Ziese, M.: GPCC Full Data Reanalysis Version 5" providing high-quality gridded monthly precipitation data for the global land-surface is public available since December 2010, Tech. Rep. December, GPCC Status Report, https://www.dwd.de/EN/ourservices/gpcc/reports_publications/ GPCC_status_report_2010.pdf?_blob=publicationFile \&v=3 (last access: 18 October 2015) 2010.

Saadi, S., Todorovic, M., Tanasijevic, L., Pereira, L. S., Pizzigalli, C., and Lionello, P.: Climate change and Mediterranean agriculture: Impacts on winter wheat and tomato crop evapotranspiration, irrigation requirements and yield, Agr. Water Manage., 147, 103-115, 2015.

Schaphoff, S., Heyder, U., Ostberg, S., Gerten, D., Heinke, J., and Lucht, W.: Contribution of permafrost soils to the global carbon budget, Environ. Res. Lett., 8, 014026, doi:10.1088/17489326/8/1/014026, 2013.

Schewe, J., Heinke, J., Gerten, D., Haddeland, I., Arnell, N. W., Clark, D. B., Dankers, R., Eisner, S., Fekete, B. M., ColónGonzález, F. J., Gosling, S. N., Kim, H., Liu, X., Masaki, Y., Portmann, F. T., Satoh, Y., Stacke, T., Tang, Q., Wada, Y., Wisser, D., Albrecht, T., Frieler, K., Piontek, F., Warszawski, L., and Kabat, P.: Multimodel assessment of water scarcity under climate change, P. Natl. Acad. Sci. USA, 111, 3245-3250, doi:10.1073/pnas.1222460110, 2013.

Siebert, S., Burke, J., Faures, J. M., Frenken, K., Hoogeveen, J., Döll, P., and Portmann, F. T.: Groundwater use for irrigation - a global inventory, Hydrol. Earth Syst. Sci., 14, 1863-1880, doi:10.5194/hess-14-1863-2010, 2010.

Sitch, S., Smith, B., Prentice, C., Arneth, A., Bondeau, A., Cramer, W., Kaplan, J. O., Levis, S., Lucht, W., Sykes, M. T., Thonike, K., and Venevsky, S.: Evaluation of ecosystem dynamics, plant geography and terrestrial carbon cycling in the LPJ dynamic global vegetation model, Global Change Biol., 9, 161-185, 2003.

Souissi, I., Temani, N., and Belhouchette, H.: Vulnerability of Mediterranean agricultural systems to climate: from regional to field scale analysis, in: Climate Vulnerability, Understanding and addressing threats to essential resources, edited by: Pielke Sr., R. A., Elsevier, Amsterdam, the Netherlands, Oxford, UK, Burlington, USA, 89-103, doi:10.1016/B978-0-12-384703-4.00221-5, 2013.

Soussana, J. F., Graux, A.-I., and Tubiello, F. N.: Improving the use of modelling for projections of climate change impacts on crops and pastures, J. Exp. Bot., 61, 2217-2228, 2010.

Tanasijevic, L., Todorovic, M., Pereira, J. S. , Pizzigalli, C., and Lionello, P.: Impacts of climate change on olive crop evapotranspiration and irrigation requirements in the Mediterranean region, Agr. Water Manage.,114, 54-68, doi:10.1016/j.agwat.2014.05.019, 2014.

Teyssier, F.: Les consommations d'eau pour irrigation en MidiPyrénées, 42 pp., http://portaildoc.oieau.fr/entrepotsOAI/AEAG/ 44/221037/221037_doc.pdf (last access: 2 January 2015), 2006.

Tubiello, F. N., Amthor, J. S., Boote, K. J., Donatelli, M., Easterling, W., Fischer, G., Gifford, R. M., Howden, M., Reilly, J., and Rosenzweig, C.: "Crop Response to Elevated $\mathrm{CO}_{2}$ and World 
Food Supply. A Comment on 'Food for Thought ...' by Long et al. Science 312, 1918-1921, 2006”, Eur. J. Agron., 26, 215-223, 2007.

United Nations: Department of Economic and Social Affairs, Population Division, World Population Prospects: The 2012 Revision, DVD Edition, New York, USA, 2013.

United Nations: World Urbanization Prospects, Department of Economic and Social Affaires, UN, New York, 2014.

Vautard, R., Gobiet, A., Sobolowski, S., Kjellström, E., Stegehuis, A., Watkiss, P., Mendlik, T., Landgren, O., Nikulin, G., Teichmann, C., and Jacob, D.: The European climate under a $2{ }^{\circ} \mathrm{C}$ global warming, Environ. Res. Lett., 9, 034006, doi:10.1088/1748-9326/9/3/034006, 2014.
Voloudakis, D., Karamanos, A., Economou, G., Kalivas, D., Vahamidis, P., Kotoulas, V., Kapsomenakis, J., and Zerefos, C.: Prediction of climate change impacts on cotton yields in Greece under eight climatic models using the AquaCrop crop simulation model and discriminant function analysis, Agr. Water Manage., 147, 116-128, 2015.

Vörösmarty, C. J., Green, P., Salisbury, J., and Lammers, R. B.: Global water resources: Vulnerability from climate change and population growth, Science, 289, 284-288, 2000.

Wada, Y., van Beek L. P. H., van Kempen, C. M., Reckman, J. W. T. M., Vasak, S., and Bierkens, M. F. P.: Global depletion of groundwater resources, Geophys. Res. Lett., 37, L20402, doi:10.1029/2010GL044571, 2010. 